\title{
New Waste Calciner High Temperature Operation
}

M. C. Swenson

September 2000

Idaho National Engineering and Environmental Laboratory Bechtel BWXT Idaho, LLC 


\title{
New Waste Calciner High Temperature Operation
}

\author{
Michael C. Swenson
}

September 2000

\section{Idaho National Engineering and Environmental Laboratory High Level Waste Program Division Idaho Falls, Idaho 83415}

Prepared for the

U.S. Department of Energy

Assistant Secretary for Environmental Management Under DOE Idaho Operations Office

Contract DE-AC07-99ID13727 


\begin{abstract}
A new Calciner flowsheet has been developed to process the sodium-bearing waste (SBW) in the INTEC Tank Farm. The new flowsheet increases the normal Calciner operating temperature from $500^{\circ} \mathrm{C}$ to $600^{\circ} \mathrm{C}$. At the elevated temperature, sodium in the waste forms stable aluminates, instead of nitrates that melt at calcining temperatures. From March through May 2000, the new hightemperature flowsheet was tested in the New Waste Calcining Facility (NWCF) Calciner. Specific test criteria for various Calciner systems (feed, fuel, quench, off-gas, etc.) were established to evaluate the long-term operability of the high-temperature flowsheet. This report compares in detail the Calciner process data with the test criteria. The Calciner systems met or exceeded all test criteria. The new flowsheet is a viable, long-term method of calcining SBW. Implementation of the flowsheet will significantly increase the calcining rate of SBW and reduce the amount of calcine produced by reducing the amount of chemical additives to the Calciner. This will help meet future waste processing milestones and regulatory needs such as emptying the Tank Farm.
\end{abstract}




\section{SUMMARY}

This report contains background information on sodium-bearing waste calcination, the development of a new high-temperature Calciner flowsheet, a detailed description of key Calciner operating parameters, and test results from a high-temperature Calciner flowsheet test conducted in April and May 2000.

In order to meet State Settlement Agreement milestones, process development personnel developed a new Calciner flowsheet to increase the rate at which sodium-bearing waste can be calcined. Sodium is a major component of the existing INTEC Tank Farm waste. The new flowsheet involves operating the Calciner at $600^{\circ} \mathrm{C}$ instead of its historical value of $500^{\circ} \mathrm{C}$. When calcined at $500^{\circ} \mathrm{C}$, sodium forms nitrates that have melting points below the operating temperature. Formation of solids with melting points below the operating temperature results in fluidized bed agglomeration and Calciner shutdown. Historically, sodiumbearing waste has been blended with other Tank Farm waste or non-radioactive chemicals in order to avoid the agglomeration problem. Sodium forms aluminates at the $600^{\circ} \mathrm{C}$ operating temperature. Sodium aluminate is a stable solid at calcining temperatures, eliminating the problem of bed agglomeration due to melting calcine solids. The new flowsheet significantly reduces the amount of non-radioactive chemical additives required to calcine sodium-bearing waste and thus increases the Calciner net processing rate.

The high-temperature flowsheet was tested in the Calciner located in the New Waste Calcining Facility (NWCF) for two brief periods (2 to 3 weeks each) in April and May 1999. Unfortunately, an unscheduled shutdown of the Calciner ended the 1999 high-temperature test before it could be proven as a long-term, viable flowsheet. A two-month, high-temperature test was conducted in April and May 2000. That test was extremely successful. There were no significant problems with either the Calciner equipment or flowsheet during the operation. The various Calciner operating systems met or exceeded all significant high-temperature test criteria. The most difficult Tank Farm flowsheet was calcined, and the amount of sodium waste contained in each feed batch exceeded even the optimistic feed-blend test criteria. Chloride volatility from the Calciner into the quench system improved (decreased) significantly over that of historical operation. Consequently, there was no quench solution returned to the Tank Farm during the high-temperature run. The test was long enough to prove the new high-temperature flowsheet is a viable long-term method of waste processing. 


\section{ACNOWLEDGEMENTS}

I wish to thank J. P. Law for his help in compiling the feed and sample data used in this report. I also thank W. B. Palmer, J. P. Law, M. W. Patterson, and J. I. Pruitt for their review and comments on the document. 


\section{CONTENTS}

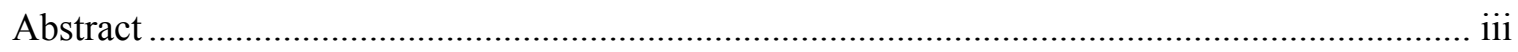

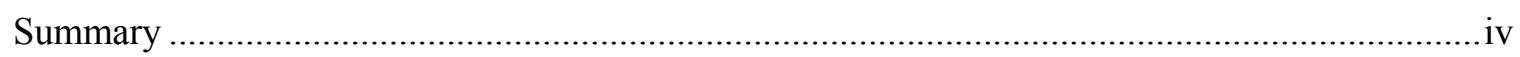

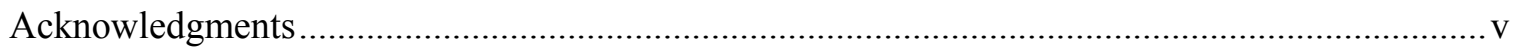

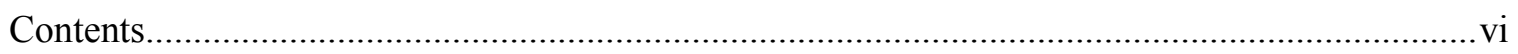

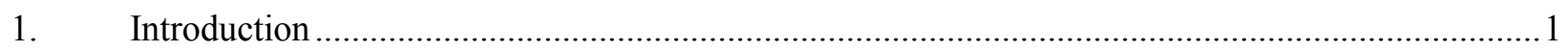

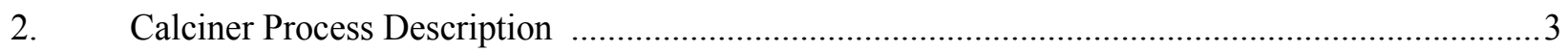

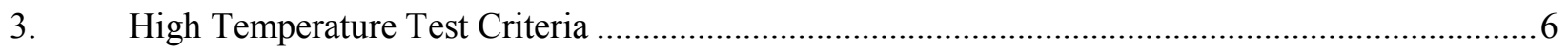

4. High Temperature Operation Results

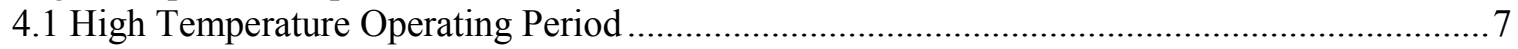

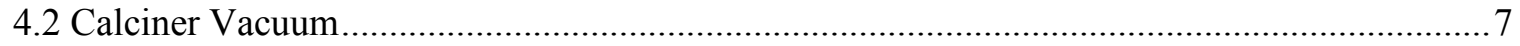

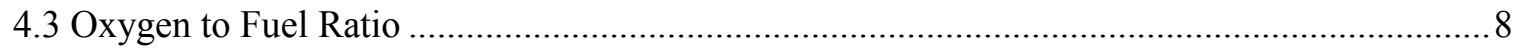

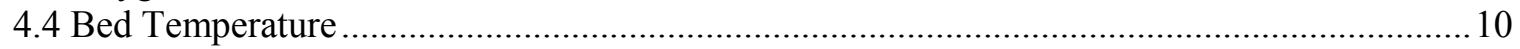

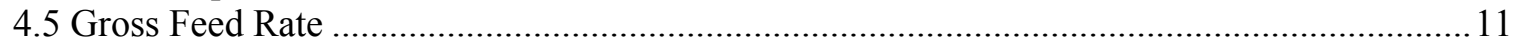

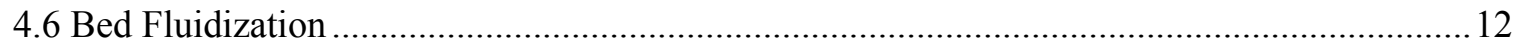

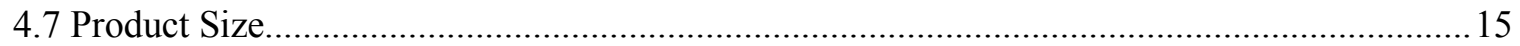

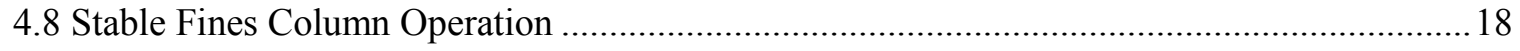

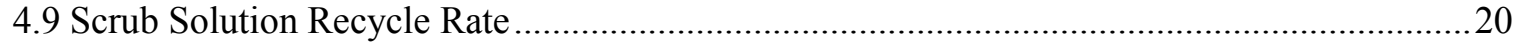

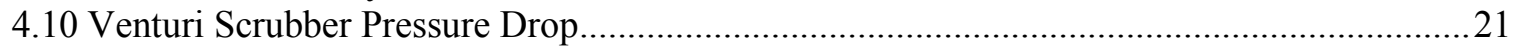

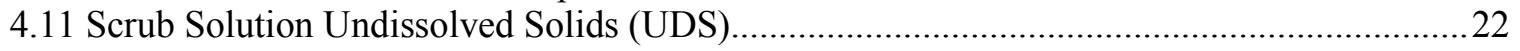

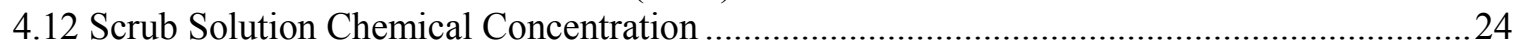

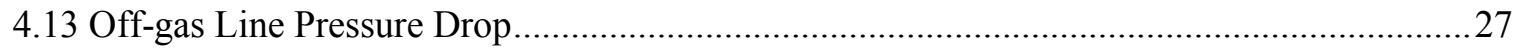

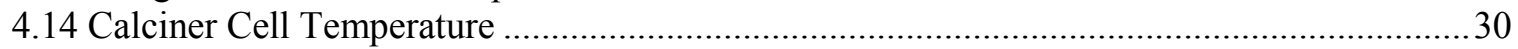

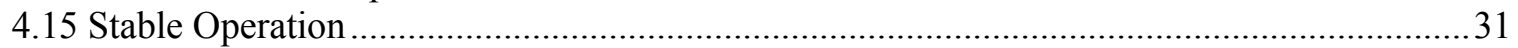

5. Significant Non-criteria Calciner Data

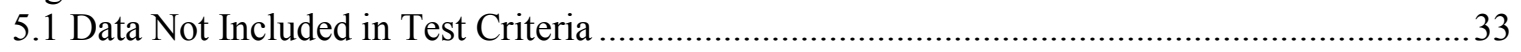

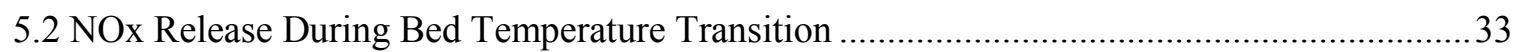

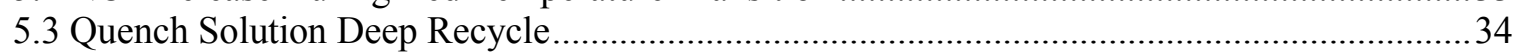

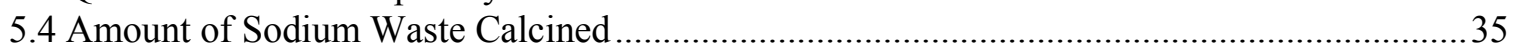

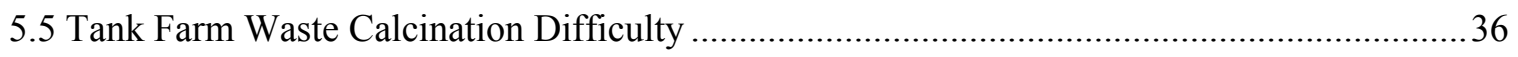

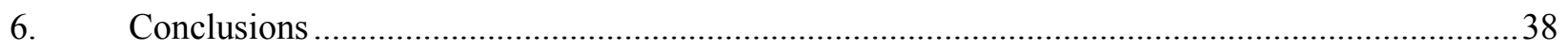

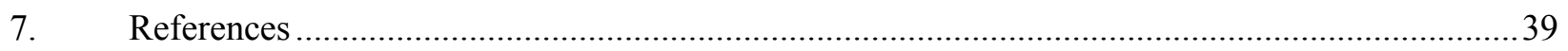




\section{FIGURES}

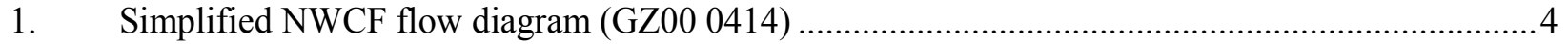

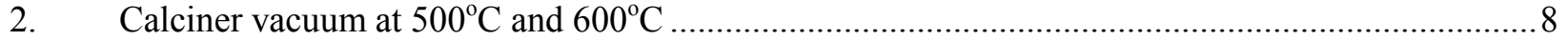

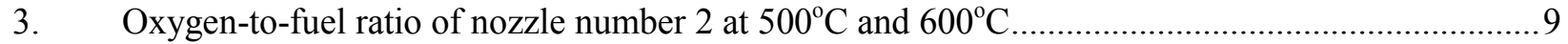

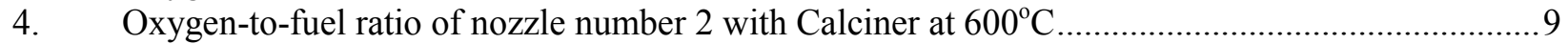

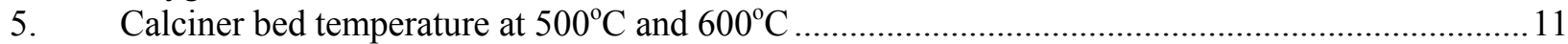

6. Average Calciner feed rate during March and April 2000 .................................................. 12

7. Calciner bed temperature disparities in 1993 (Calciner at $500^{\circ} \mathrm{C}$ ) ............................................ 13

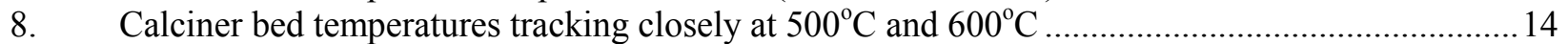

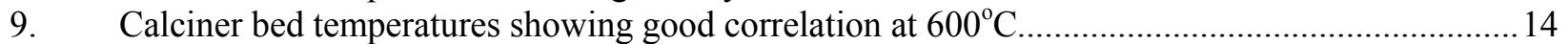

10. Calciner bed temperatures during a temperature oscillation (Calciner at $\left.600^{\circ} \mathrm{C}\right) \ldots \ldots \ldots \ldots \ldots \ldots \ldots . . . . . . . .15$

11. Plot of calcine particle size (MMPD) during Calciner operation in 2000 ....................................16

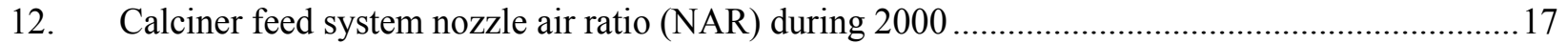

13. Bed level in the Calciner showing normal bed growth and removal in May 2000 ......................18

14. Fines column level before and after the high-temperature transition on March 25, 2000.............19

15. High-temperature scrub build-up rate (average $32 \mathrm{gph}$ ) during May 2000..............................20

16. High-temperature Calciner feed rate (average $159 \mathrm{gph}$ ) during 2000 .......................................21

17. Venture scrubber pressure drop during April 2000 high-temperature operation ..........................22

18. Undissolved solids in the quench solution during the 2000 high-temperature operation...............23

19. Chloride concentration in the quench solution during the 2000 Calciner operation ......................25

20. Quench solution acid concentration during Calciner operation in 2000 .....................................26

21. Calciner quench solution density (specific gravity) during 2000 Calciner operation ......................22

22. Quench tower Pressure during April 1999 when the cyclone off-gas line plugged .......................28

23. Quench tower pressure during the 2000 operation with no off-gas line plugging .......................29

24. Special off-gas line pressure-drop data during April 2000 high-temperature operation................29

25. Calciner cell temperature in 2000 during the high-temperature transition.....................................30

26. Calciner cell and air conditioning system temperatures during high-temperature operation...........31

27. Elevated NOx release during Calciner high-temperature transition in March 2000 .....................33

28. Normal NOx release during Calciner high-temperature transition in March 1999 .........................34

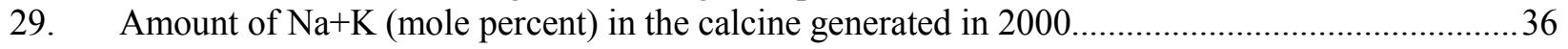

\section{TABLES}

1. Tank Farm VES-WM-189 waste composition (sampled November 1998) ..... 


\section{New Waste Calciner High Temperature Operation}

\section{INTRODUCTION}

The DOE signed a Settlement Agreement with the State of Idaho to calcine the sodium-bearing waste (SBW) stored in the INTEC Tank Farm by December 31, 2012. The Calciner has processed SBW waste since it began radioactive operations in 1982. However, the rate at which SBW has been calcined is low. SBW, as the name implies, contains a large amount of sodium (and potassium) salts. Sodium forms solids, primarily nitrates, in the Calciner that have melting points below the historical NWCF Calciner operating temperature of $500^{\circ} \mathrm{C}$. Significant quantities of sodium in the Calciner feed create "sticky" calcine due to the melting of sodium nitrate at normal operating temperatures. This stickiness results in the calcine particles forming agglomerates. The calcination process is dependent on having a wellfluidized, free-flowing, granular bed. An agglomerated bed is difficult to maintain in a well-fluidized condition. Historically, this problem has been resolved by blending small quantities of SBW with other, more easily calcinable waste. The easily calcinable waste was the first cycle raffinate, generated by reprocessing nuclear fuel. All of the first cycle waste has been calcined, and it is no longer being generated since fuel reprocessing has stopped. In order to continue calcination of the SBW, nonradioactive materials can be added to the SBW. This makes the SBW similar in chemistry to that obtained by blending SBW with first cycle raffinates. However, the chemical addition reduces the net processing rate of SBW and creates additional calcine.

INTEC process development personnel evaluated several different calcining options in order to increase the net processing rate of SBW. The evaluation concluded a much more efficient calcination flowsheet was possible by increasing the normal operating temperature of the Calciner from $500^{\circ} \mathrm{C}$ to $600^{\circ} \mathrm{C}$. A thorough engineering evaluation (Reference 1) concluded the new flowsheet could be implemented with only relatively minor maintenance work and procedural changes. The high-temperature flowsheet results in the formation of sodium aluminate, instead of sodium nitrate, in the calcine. Sodium aluminate is a stable solid at calcining temperatures. This eliminates the fluidized bed agglomeration problem associated with the formation of low-melting, sticky, sodium nitrate. It also significantly decreases the amount of non-radioactive chemical additives that must be used. This increases the net feed rate of SBW through the Calciner, and reduces the amount of calcine generated.

The high-temperature flowsheet was initially tested in the Calciner in 1999 (Reference 2). In April and May of 1999 the Calciner operated with the high-temperature flowsheet for two separate periods of time. Each operating period was two to three weeks in length. In general, high-temperature operation in 1999 was successful. However, an unscheduled shutdown of the Calciner due to a restriction of the process off-gas line prevented the demonstration of the long-term viability of the high-temperature flowsheet. The shutdown also raised questions about whether the off-gas line restriction was caused by the hightemperature flowsheet. An analysis (Reference 3) of the operating data identified the cause of the shutdown. The cause was the renitration (absorption of NOx) of fines in the off-gas line. The hightemperature flowsheet did not cause the off-gas line restriction. Calciner operating procedures were changed to prevent the conditions that resulted in the off-gas line restriction.

Because the 1999 high-temperature operation was so short, another high-temperature run was needed to fully demonstrate the long-time viability of the flowsheet. Another run would also prove the off-gas line restriction would not form during high-temperature operation. A long-term, high-temperature demonstration would also be useful to validate the results of pilot plant tests on calcination flowsheets. The results of the pilot plant studies were used as inputs to various INTEC waste processing options and 
schedules included in the Idaho HLW \& Facilities Disposition Environmental Impact Statement. Validation of the pilot plant studies would increase confidence in achieving future milestones via the calcination process.

In order to judge the success of the high-temperature operation, a set of Calciner test criteria was developed and transmitted to DOE (Reference 4). Personnel knowledgeable of the Calciner developed the criteria. The criteria represent key Calciner operating parameters most likely to be affected by the change in operating temperature from $500^{\circ} \mathrm{C}$ to $600^{\circ} \mathrm{C}$. The criteria were based on historical, successful operation of the Calciner. The criteria included ranges for operating parameters at which the Calciner had demonstrated years of stable operation.

This report briefly describes the entire calcination process and then concentrates on how the Calciner performed against the test criteria during a two-month high-temperature operation from March to May 2000 . 


\section{CALCINER PROCESS DESCRIPTION}

The calcining process was developed to convert liquid radioactive waste into granular, solid calcine material. This is done by evaporating liquid waste in the fluidized bed of the Calciner vessel. The calcination process converts the dissolved metals and fission products in the liquid into solid salts and oxides. Calcine is pneumatically transferred from the Calciner vessel to calcine storage bins. Historically, the NWCF Calciner has operated at $500^{\circ} \mathrm{C}$. The new high-temperature flowsheet increases the calcination temperature from $500^{\circ} \mathrm{C}$ to $600^{\circ} \mathrm{C}$.

Most of the calcining process equipment is located in shielded cells in the NWCF (CPP-659). Figure 1 is a simplified flow diagram showing most of the major process equipment. Feed solution is transferred from the Tank Farm to the NWCF into a 5000-gallon blend tank (VES-NCC-101). From the blend tank, smaller batches of waste are transferred into one of two hold tanks (VES-NCC-102 and VES-NCC-103), where the waste is mixed with chemical additives such as aluminum nitrate, calcium nitrate, and boric acid. Recycled solution from the off-gas quench system is also added to the waste in the hold tanks. The hold tanks are normally used in an alternating batch mode. One vessel is used as the source of Calciner feed solution, while the other receives feed solution and chemical additives.

A small feed tank (VES-NCC-104) receives blended feed from either hold tank. Feed solution flows by gravity from the feed tank to the Calciner vessel (VES-NCC-105) through any of four parallel transfer lines. The four lines are identical in function and provide redundancy in case of problems such as plugs, instrument failures, etc. At the Calciner vessel, the feed enters an atomizing nozzle where it is mixed with high-pressure air and sprayed into the fluidized Calciner bed. The size of the calcine particles is controlled primarily by the flow of atomizing air to the feed nozzles. Higher airflows break up the bed and result in smaller particles. In the Calciner, the atomized feed solution is vaporized in the thermally hot fluidized bed. Dissolved solids in the waste form oxides and build up in layers on the bed particles.

The bed temperature is controlled by the in-bed-combustion of kerosene, which is atomized with oxygen and sprayed into the fluidized bed. Fluidizing air is supplied by one of two fluidizing blowers (BLONCO-250-1 and NCO-BLO-250-2). Electric heaters on the fluidizing air system provide heat to the Calciner during startup prior to initiating the in-bed-combustion of kerosene. The fluidizing air also removes water vapor and gaseous combustion products from the Calciner vessel.

The fluidized bed gradually increases in volume as waste is calcined. Periodically some of the bed is removed via one of two product removal lines and pneumatically transported to a calcine solids storage facility (CSSF). The Calciner offgas passes through a high-efficiency cyclone (VES-NCC-107) immediately after leaving the Calciner vessel. The cyclone removes fine calcine particles entrained in the offgas. The removed particles fall by gravity into the tall fines column, a cyclone disengaging leg. The fine particles drain from the fines column into the pneumatic transport system and are conveyed with the calcine product to the CSSF. 


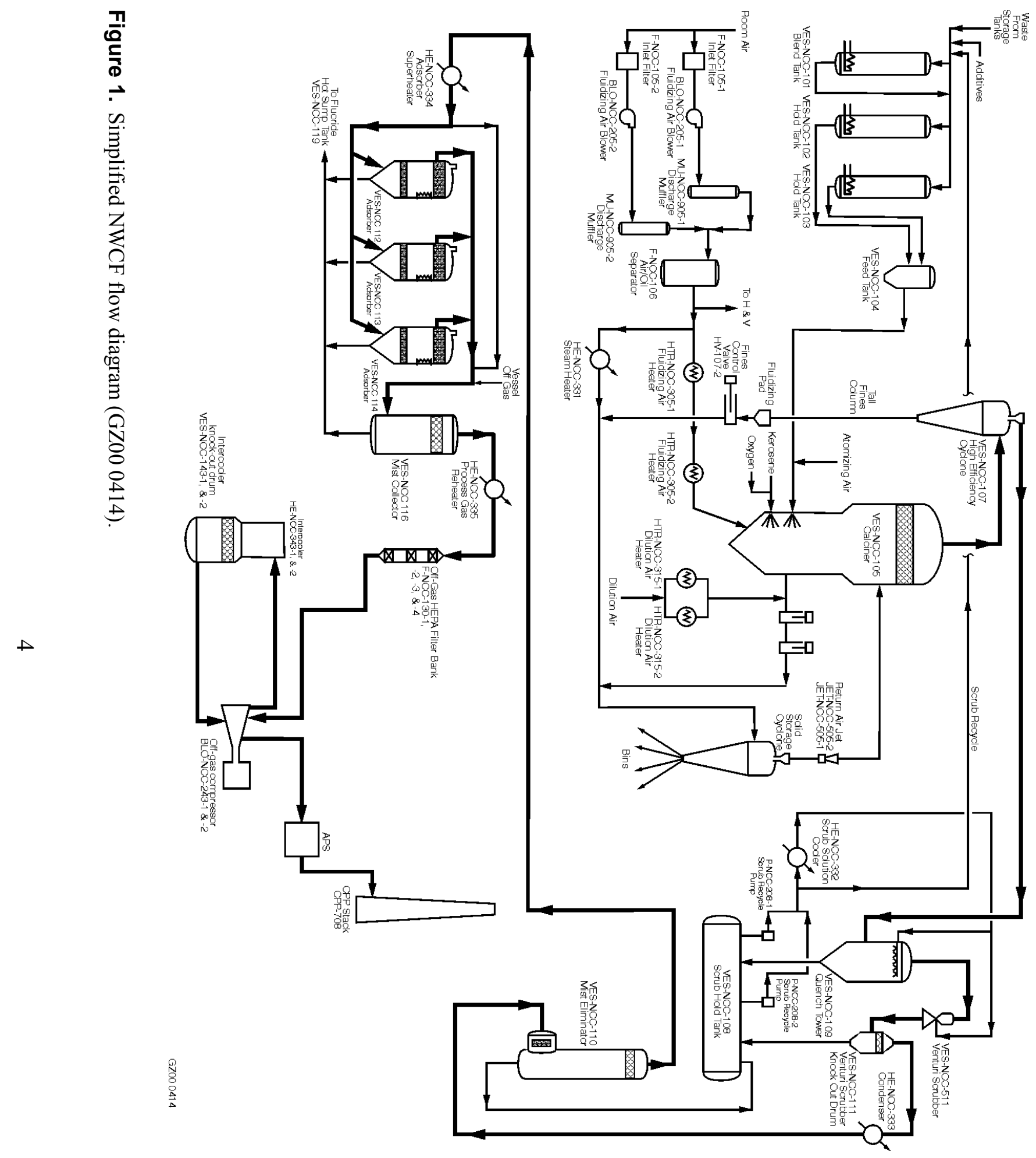


The Calciner offgas leaves the cyclone and enters the quench tower (VES-NCC-109). The hot offgas travels vertically up through the quench tower. It is cooled to about $150^{\circ} \mathrm{F}$ by a nitric acid-based quench solution sprayed downward through the quench tower, countercurrent to the offgas flow. After the quench tower, the offgas goes to a venturi scrubber (VS-NCC-511). There the gas is cleaned using a spray of quench solution to remove micron-sized particles. Following the venturi scrubber, a mist eliminator (VES-NCC-111) removes fine mists and aerosols generated in the venturi scrubber. Solution from the quench tower and venturi scrubber drains by gravity to a quench solution hold tank (VES-NCC108). Quench solution is circulated from the hold tank to the quench tower and venturi scrubber using one of two quench pumps (P-NCC-208-1 and P-NCC-208-2). Nitric acid, continuously added to the quench hold tank, dissolves the fine calcine particles removed from the offgas. The volume of quench solution increases as acid is added to the quench hold tank. Periodically, a portion of the quench solution is transferred to the feed hold tanks, where it is mixed with the Tank Farm waste and fed to the Calciner. Following VES-NCC-111 the offgas goes through a condenser (HE-NCC-333), which is not normally used, and another mist eliminator (VES-NCC-110), which contains two meshes in series to remove fine mists and aerosols. The mist eliminator meshes in vessels NCC-111 and NCC-110 become progressively finer to remove smaller and smaller mists and aerosols from the offgas.

Downstream of the vessel 110 mist eliminator, the offgas goes through a superheater (HE-NCC-334) which is normally not used, and then to one of three parallel ruthenium adsorbers (VES-NCC-112, VESNCC-113, and VES-NCC-114). The adsorbers were originally designed to remove volatile ruthenium from the offgas. However, the amount of volatile ruthenium has usually been negligible, so their primary purpose is as a roughing filter upstream of the HEPA filters. Following the ruthenium adsorbers, the Calciner offgas combines with the vessel offgas. The vessel offgas consists of storage vessel gases such as instrument air, sparge air, vapor space gases discharged when a vessel fills with liquid, etc. This flow is typically small in volume and not highly contaminated with fine calcine particles, so it bypasses much of the Calciner off-gas clean-up equipment.

The combined Calciner and vessel off-gas streams go through a mist eliminator (VES-NCC-116) and a superheater (HE-NCC-335) where the gas temperature is raised to approximately $200^{\circ} \mathrm{F}$. The extra heat assures moisture in the offgas won't condense in the downstream HEPA filters. The superheated offgas then goes to four parallel banks of HEPA filters. Each filter bank consists of three HEPA filters in series. Two banks of filters are normally on line, and two banks are normally in reserve in case the on-line filters require replacement.

Following the HEPA filters, the offgas is exhausted from the NWCF via one of two parallel gas compressors (BLO-NCC-243-1 and BLO-NCC-243-2). These compressors provide the motive force to maintain the entire Calciner system under a vacuum and send the offgas from the NWCF to a backup, offgas treatment facility, the Atmospheric Protection System (APS). After treatment in the APS, the offgas is exhausted to the atmosphere via the main INTEC stack (CPP-708). 


\section{HIGH TEMPERATURE TEST CRITERIA}

Prior to the start of the high-temperature test, a set of test criteria was developed to evaluate the success of the high-temperature flowsheet. The test criteria were formally transmitted to DOE-ID (Reference 4). Personnel with extensive calcination background and experience established the criteria. The criteria consisted primarily of operating parameters most likely to be affected by the high-temperature flowsheet. Each parameter had an operating range for which the Calciner had many years of successful operating experience. Operation of the Calciner within the criteria ranges would demonstrate the success of the high-temperature Calciner flowsheet. Successful steady-state operation at parameter values outside the criteria ranges was also possible. However, such operation had not been routinely demonstrated in past Calciner operating campaigns. Such operation would have to be carefully monitored and evaluated to assure successful operation.

The following fourteen criteria were established to measure the success of the high-temperature flowsheet:

1. The Calciner vacuum maintained with 5 inches of water from its set point (normally 42 inches of water).

2. The oxygen/fuel ratio controlled to a ratio between 1800 and 2200 .

3. Bed temperature maintained at $600 \pm 25^{\circ} \mathrm{C}$.

4. With all four fuel nozzles in service, a minimum gross feed rate of 170 gph demonstrated. In the event that one fuel nozzle is out of service, a minimum gross feed rate of $130 \mathrm{gph}$ demonstrated using the remaining three fuel nozzles.

5. Fluidization maintained across the bed as indicated by consistent temperature trends on temperature indicators $\mathrm{T}-105-8, \mathrm{~T}-105-9$, and $\mathrm{T}-105-10$ or temperature differences of no more than $40^{\circ} \mathrm{F}$ between the readings on temperature indicators $\mathrm{T}-105-8, \mathrm{~T}-105-9$, and $\mathrm{T}-105-10$.

6. Product size (MMPD) controlled between $0.25 \mathrm{~mm}$ and $0.60 \mathrm{~mm}$ for each feed blend ratio by adjusting the nozzle air ratio (NAR). NAR maintained below 450 during high-temperature operation.

7. Stable fines column operation demonstrated by maintaining a level of 25-175 inches on level indicator L107-1C and by a lack of plugging or bridging that cannot be corrected by normal column air blasting procedures.

8. The scrubbing solution recycle rate maintained at less than $20 \%$.

9. A pressure drop of at least 50 inches of water maintained through the venture scrubber.

10. The scrubbing solution undissolved solids concentration maintained at less than $15 \mathrm{~g} / \mathrm{L}$.

11. The chloride concentration $(<5000 \mu \mathrm{g} / \mathrm{mL})$, acid normality $(>0.5 \underline{\mathrm{M}})$, and specific gravity $(<1.4)$ of the scrubbing solution maintained with limits using only means normally employed when operating at $500^{\circ} \mathrm{C}$.

12. The pressure drop from the Calciner to Quench Tower maintained at less than 15 inches of water.

13. The Calciner cell temperature maintained at or below $160^{\circ} \mathrm{F}$.

14. Operation for 30 days at a stable feed blend ratio. 


\section{HIGH TEMPERATURE OPERATION RESULTS}

\subsection{High Temperature Operating Period}

After completing preparations for the high-temperature test, Calciner operation resumed on March 8, 2000 with the start of the in-bed-combustion system. The Calciner began processing non-radioactive feed, and then switched to radioactive waste solution on March 15, 2000. The initial operating temperature was $500^{\circ} \mathrm{C}$ to establish the entire Calciner process was operating normally with no equipment problems that might affect the high-temperature test. On March 25, 2000 operating personnel increased the bed temperature to $600^{\circ} \mathrm{C}$ and began the high-temperature test. From March 25 to May 24 the Calciner operated continuously at $600^{\circ} \mathrm{C}$ and processed SBW from the Tank Farm (VES-WM-189). On May 24, the feed solution was changed to a non-radioactive blend to prepare for Calciner shutdown. The Calciner (in-bed-combustion) was shut off on May 27, 2000. The calcine bed material was transported to the CSSF and the off-gas compressors were shut down on May 31 to comply with a commitment to the State to put the Calciner in standby mode by June 1, 2000.

Section 4 of this report discusses Calciner operation relative to the high-temperature criteria. A discussion of the data is included with each criterion to indicate why each parameter is important to the Calciner process, and whether or not the criterion was met. In most cases, a data plot is included to illustrate the points made in the discussion. The order of criterion discussion is the same as in the DOE transmittal.

\subsection{Calciner Vacuum}

Criterion 1: The Calciner vacuum maintained with 5 inches of water from its set point (normally 42 inches of water).

The Calciner vacuum is a good indication of the overall "health" of the off-gas treatment system. Most of the calcining process is an extensive gas clean-up system. This system is maintained under vacuum for contamination control. A process change (such as high-temperature) has the potential to affect the off-gas system in a number of ways. These include increasing the flow of offgas through the system due to the increase in combustion products resulting from the burning of more kerosene. The gas flow also increases due to the higher gas temperature and resulting decrease in gas density. Increases in gas flow will increase pressure drops through the off-gas equipment and piping. Too much of an increase could be more than the off-gas system can accommodate. This could result in lower off-gas cleanup efficiency, or less contamination control due to loss of vacuum.

The high-temperature test run met the criterion to maintain stable Calciner vacuum. The increase in operating temperature resulted in only small changes in the off-gas system flows and pressure drops. Figure 2 shows the Calciner vacuum (P105-1C) data for a one-month period during March and April 2000, including the transition to the high-temperature flowsheet. 


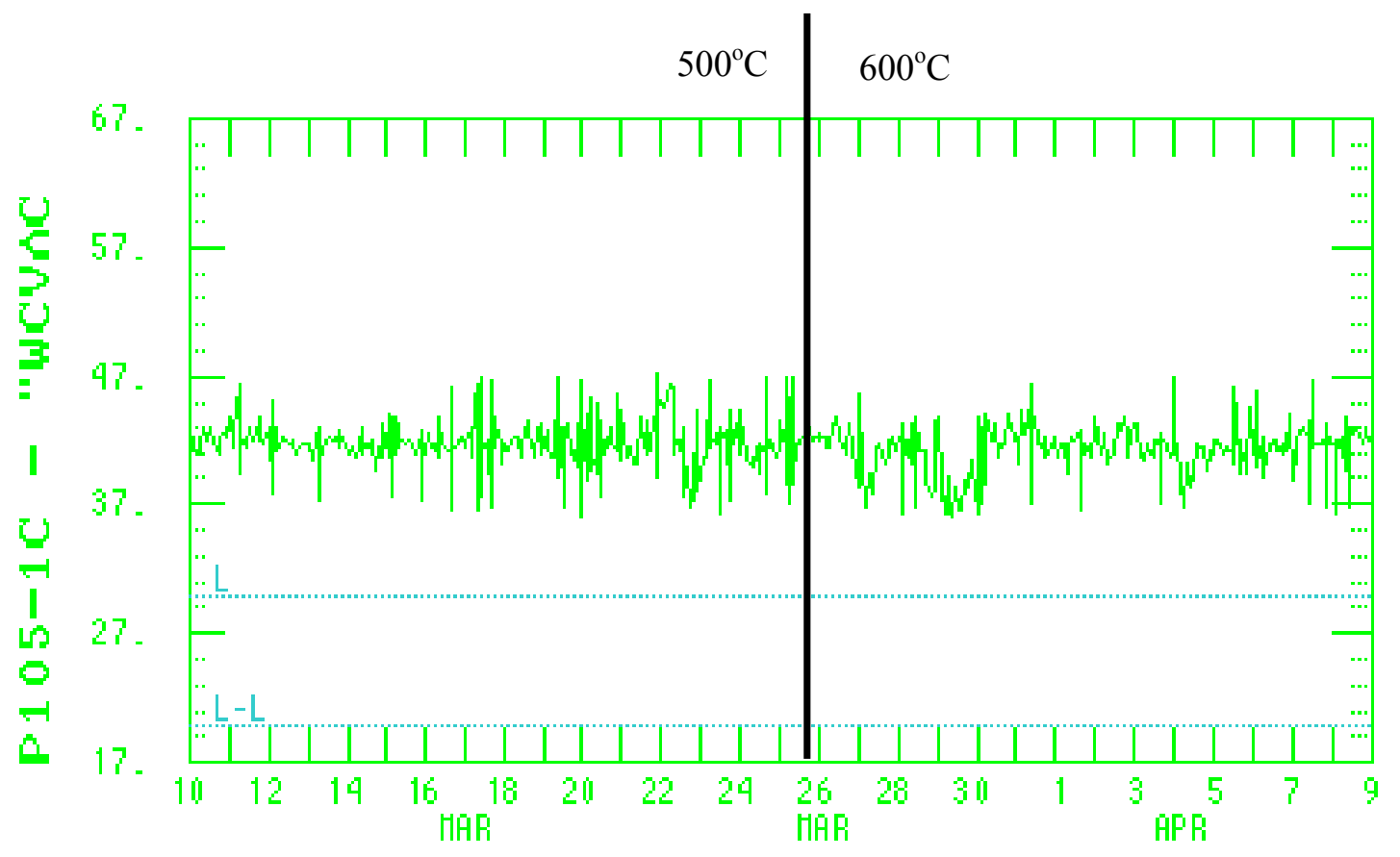

Figure 2. Calciner vacuum at $500^{\circ} \mathrm{C}$ and $600^{\circ} \mathrm{C}$.

The $500^{\circ} \mathrm{C}$ to $600^{\circ} \mathrm{C}$ transition occurred on March 25, shown as a dark line in the middle of Figure 2 . There is no difference between the Calciner vacuum control in the first half of the trend $\left(500^{\circ} \mathrm{C}\right)$ and the last half $\left(600^{\circ} \mathrm{C}\right)$. Both periods show frequent, short-term spikes in the Calciner vacuum. These spikes were usually the result of operations such as feed nozzle flushes that were routinely performed at both operating temperatures. Such spikes occasionally exceeded the 5 inches of water high-temperature criteria, but they were for very brief periods and were considered part of normal operation for both operating temperatures. There is one small dip in Calciner vacuum on March 29 to near 37 inches. This occurred when the off-gas superheater (HE-NCC-335) was flushed to remove scale. The superheater flushing operation is a normal occurrence at both operating temperatures. The Calciner vacuum returned to normal (42 inches) following the superheater flush.

\subsection{Oxygen to Fuel Ratio}

Criterion 2: The oxygen/fuel ratio controlled to a ratio between 1800 and 2200.

The oxygen-to-fuel ratio is a dimensionless ratio of the flow of oxygen to that of the kerosene. It is a significant safety parameter because the NWCF safety analysis takes credit for being able to maintain the ratio above a minimum value. The minimum value is necessary to provide enough oxygen for the combustion of kerosene. This assures unburned hydrocarbons don't accumulate in the Calciner or its offgas system. An accumulation of unburned hydrocarbons could lead to a fire or explosion in the system. The high-temperature flowsheet requires more kerosene and oxygen, at a given feed rate, to maintain the higher bed temperature. One potential high-temperature problem is a limitation in the oxygen system that might preclude delivery of the additional oxygen flow required by the high-temperature flowsheet. Such a deficiency would result in a low oxygen-to-fuel ratio. Figure 3 shows the oxygen-to-fuel ratio data for the number 2 fuel nozzle during March and April 2000. It shows the ratio in the acceptable range for both the $500^{\circ} \mathrm{C}$ and $600^{\circ} \mathrm{C}$ operating periods (before and after the March 25 temperature transition) with no real differences between the two periods. 


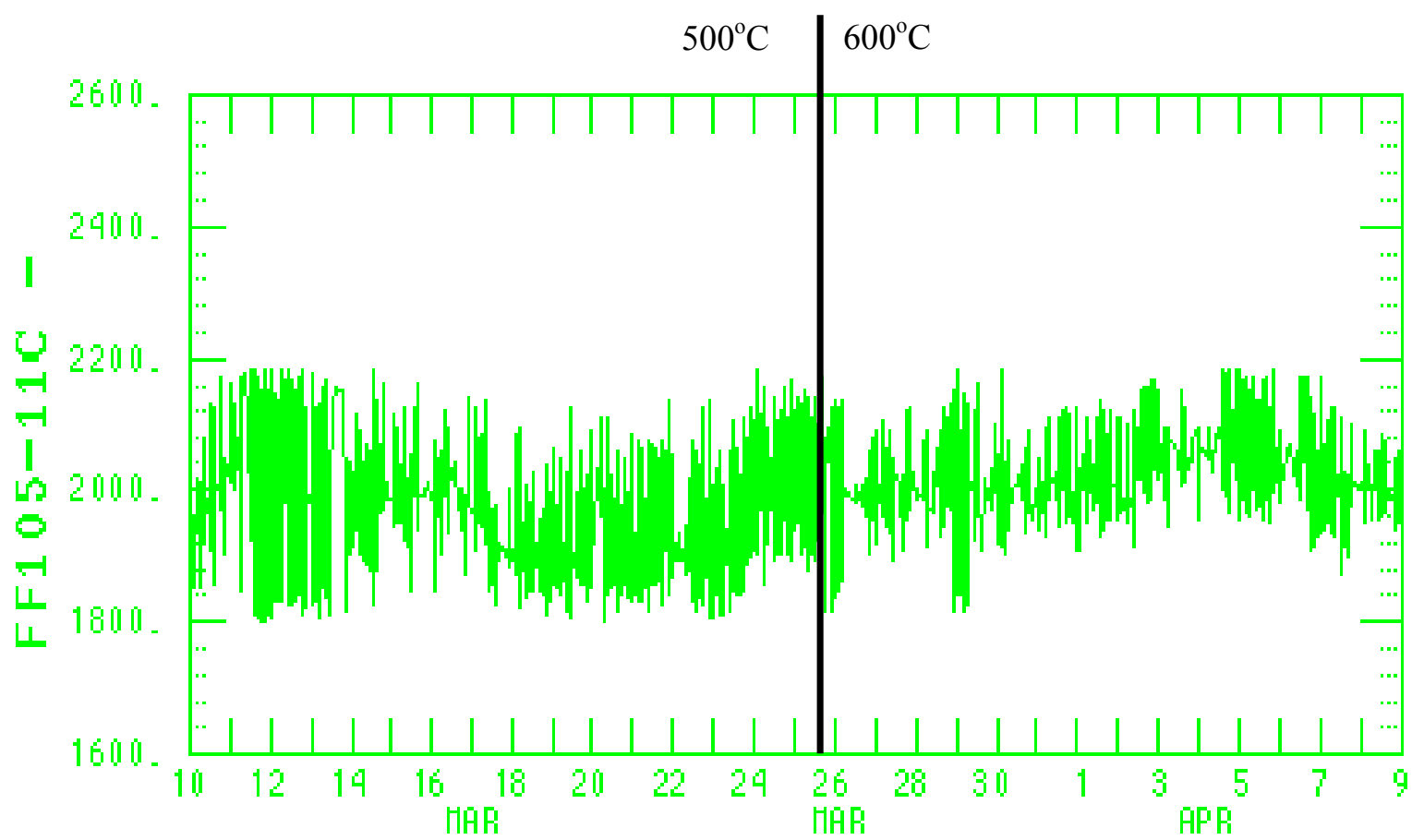

Figure 3. Oxygen-to-fuel ratio of nozzle number 2 at $500^{\circ} \mathrm{C}$ and $600^{\circ} \mathrm{C}$.

Figure 4 shows the oxygen-to-fuel ratio for April and May 2000 when the ratio was increased from 2000 to 2300 to help control calcine particle size. The ratio of 2300 was maintained through the remainder of the run. The data on Figures 3 and 4 are for nozzle number 2, but are typical of the values for all four fuel nozzles.

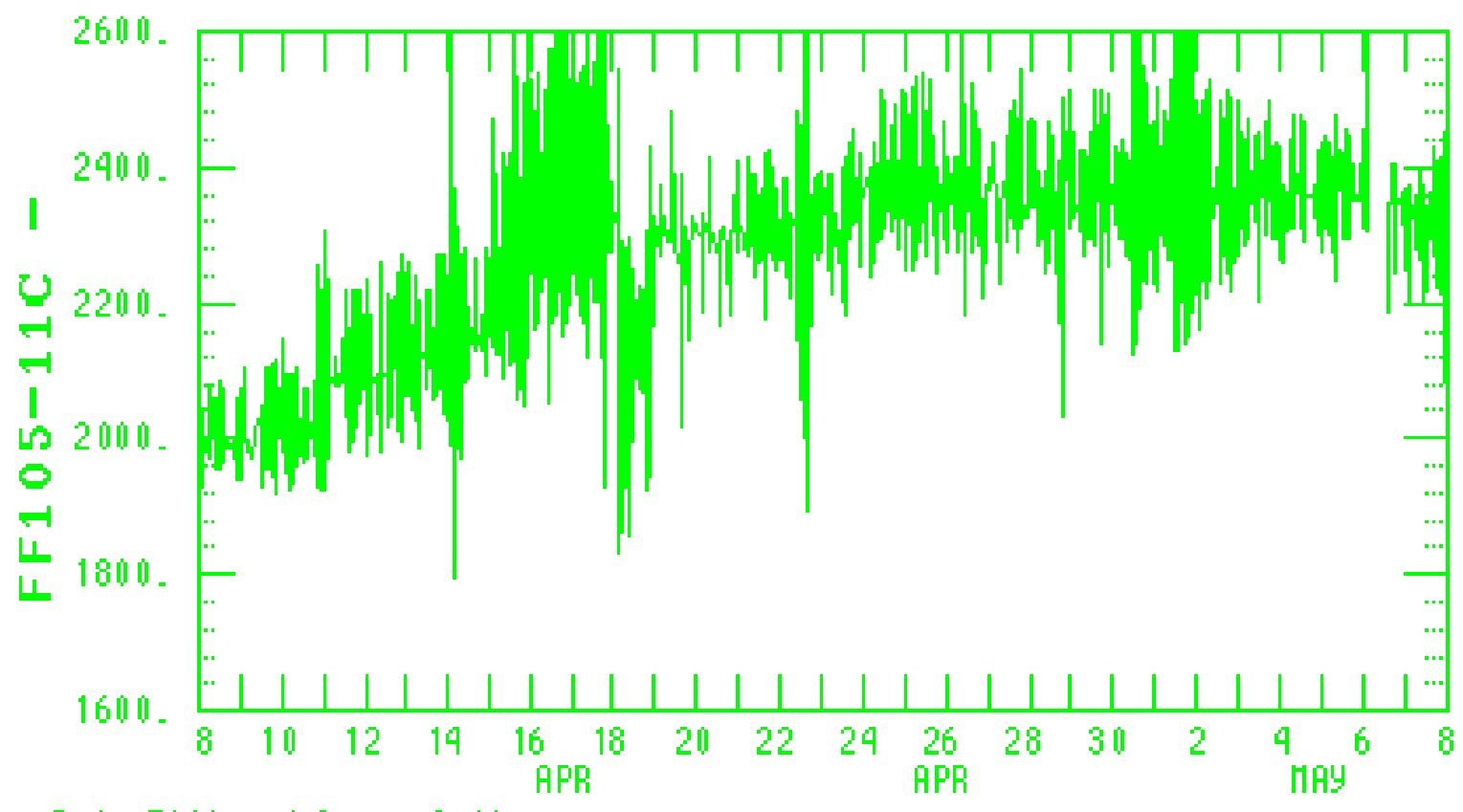

Figure 4. Oxygen-to-fuel ratio of nozzle number 2 with Calciner at $600^{\circ} \mathrm{C}$. 
Although this criterion was technically not met because it slightly exceeded the test criterion range, the operation was judged acceptable. The criterion range of 1800 to 2200 is the average historical value for this parameter, and is based on maintaining operation well above the safety value. It is important to maintain the oxygen-to-fuel ratio above the minimum value of the criterion range, as there are safety implications associated with that value. That portion of the criterion was met, and exceeded, as the high oxygen-to-fuel ratio demonstrated no potential problems exist in the oxygen supply and delivery system that would limit oxygen flow and pose a safety problem. Other than as a historical average, there is no significance in the upper value of the criterion range. A high oxygen-to-fuel ratio simply means more oxygen than required is used to burn the kerosene. The result is a small increase in the use of oxygen, an inexpensive chemical. At very high oxygen-tofuel ratios, there is a chance the required oxygen flow might exceed the range of the oxygen flow monitoring system. Such a condition would require a lower feed rate or lower temperature to reduce the demand for kerosene and oxygen. This problem did not occur during the hightemperature test. Simply increasing the range of the oxygen flow monitoring instrumentation could easily solve this potential problem. The oxygen system demonstrated adequate capacity to operate at the higher flows required by the high-temperature flowsheet. That portion of the criterion which was not met has no safety or processing significance and therefore has no bearing in the overall evaluation of the success or failure of the high-temperature test.

\subsection{Bed Temperature}

Criterion 3: Bed temperature maintained at $600 \pm 25^{\circ} \mathrm{C}$.

The bed temperature controls the flow of kerosene to the Calciner. A stable bed temperature means the kerosene system is under control. The high-temperature flowsheet requires a higher amount of kerosene to maintain the bed temperature. Any problems in the kerosene delivery system will be manifest in an inability to maintain bed temperature. In addition, drastic swings in bed temperature are undesirable because undesirable chemical reactions might occur (such as making "sticky" sodium nitrate calcine at lower temperatures). Figure 5 shows the average Calciner bed temperature during March and April 2000, including the transition to the high-temperature flowsheet. Figure 5 shows excellent bed temperature stability (within the criterion of $25^{\circ} \mathrm{C}$ ) when operating at both the $500^{\circ} \mathrm{C}$ and $600^{\circ} \mathrm{C}$ flowsheets. 


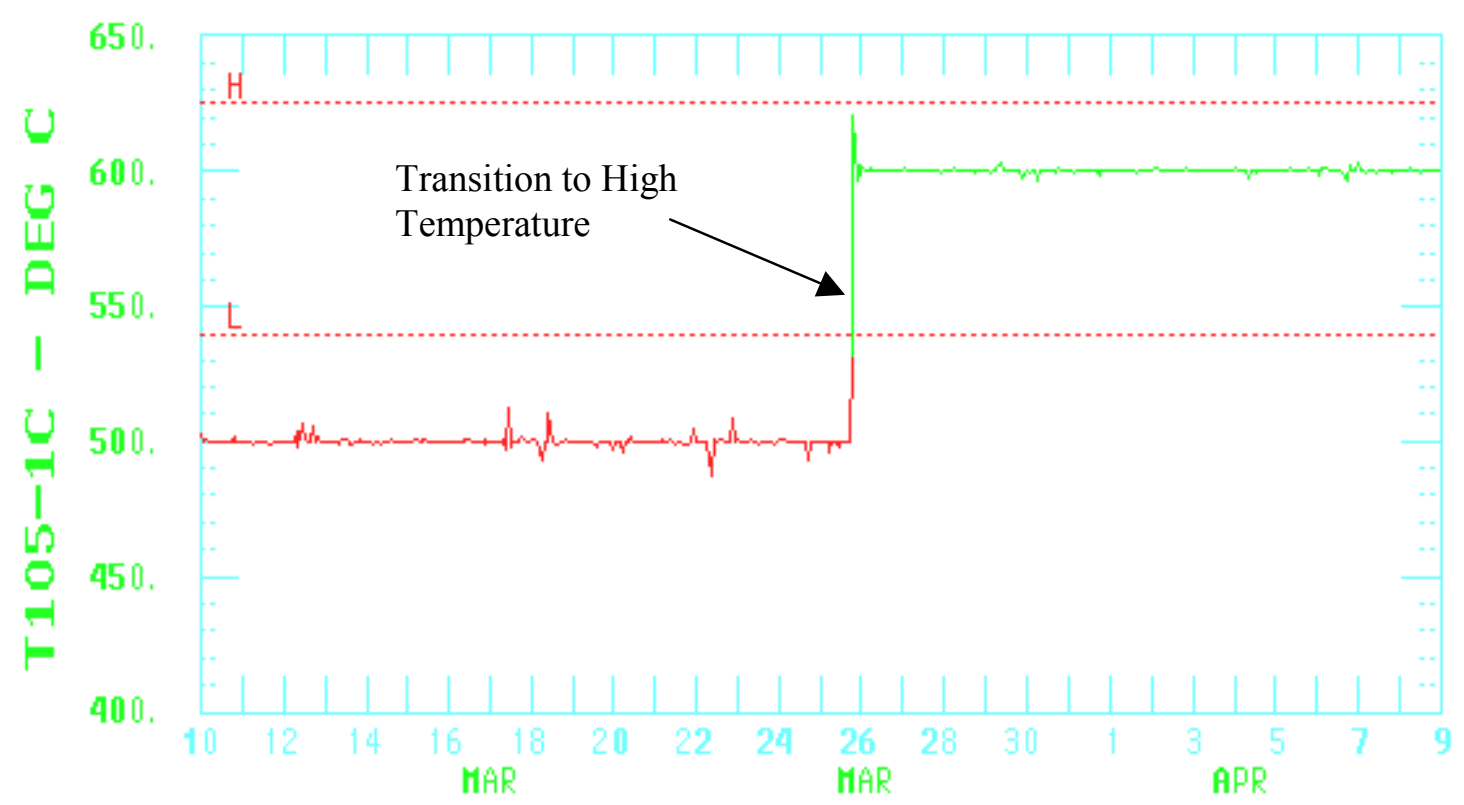

Figure 5. Calciner bed temperature at $500^{\circ} \mathrm{C}$ and $600^{\circ} \mathrm{C}$.

There were never any problems with the kerosene delivery system, the instrumentation, controls, or any other area related to the bed temperature. The high temperature test met the criterion of maintaining a stable bed temperature.

\subsection{Gross Feed Rate}

Criterion 4: With all four fuel nozzles in service, a minimum gross feed rate of $170 \mathrm{gph}$ demonstrated. In the event that one fuel nozzle is out of service, a minimum gross feed rate of 130 gph demonstrated using the remaining three fuel nozzles.

This criterion, coupled with those for Calciner vacuum, oxygen, and bed temperature, demonstrates the Calciner is capable of running at full capacity. It demonstrates there are no limitations in the fuel, oxygen, or off-gas systems. Demonstrating operation at full capacity is important since future waste processing plans have assumed certain processing rates. Demonstration of the ability to achieve these processing rates increases the probability of meeting future processing milestones. The fuel and oxygen flows are dictated by feed rate. A higher feed rate means more water to evaporate, which requires more kerosene and oxygen. Problems in the kerosene and oxygen delivery systems could be masked if the Calciner feed rate is only thirty or forty gallons per hour (gph), which would require only one-fourth the normal kerosene and oxygen flow. The Calciner vacuum and off-gas systems have similar potential limitations. The off-gas flow is directly proportional to feed rate. More feed means more water vapor and combustion products, which put a greater load on the off-gas system. Simply reducing the feed rate to reduce off-gas flow could mask severe off-gas plugging or equipment capacity problems. Running at full capacity also puts the most heat into the off-gas system and therefore tests the quench system for its capacity to remove the extra heat from the high-temperature flowsheet. Figure 6 shows the feed rate for the first month after beginning the high-temperature test. 


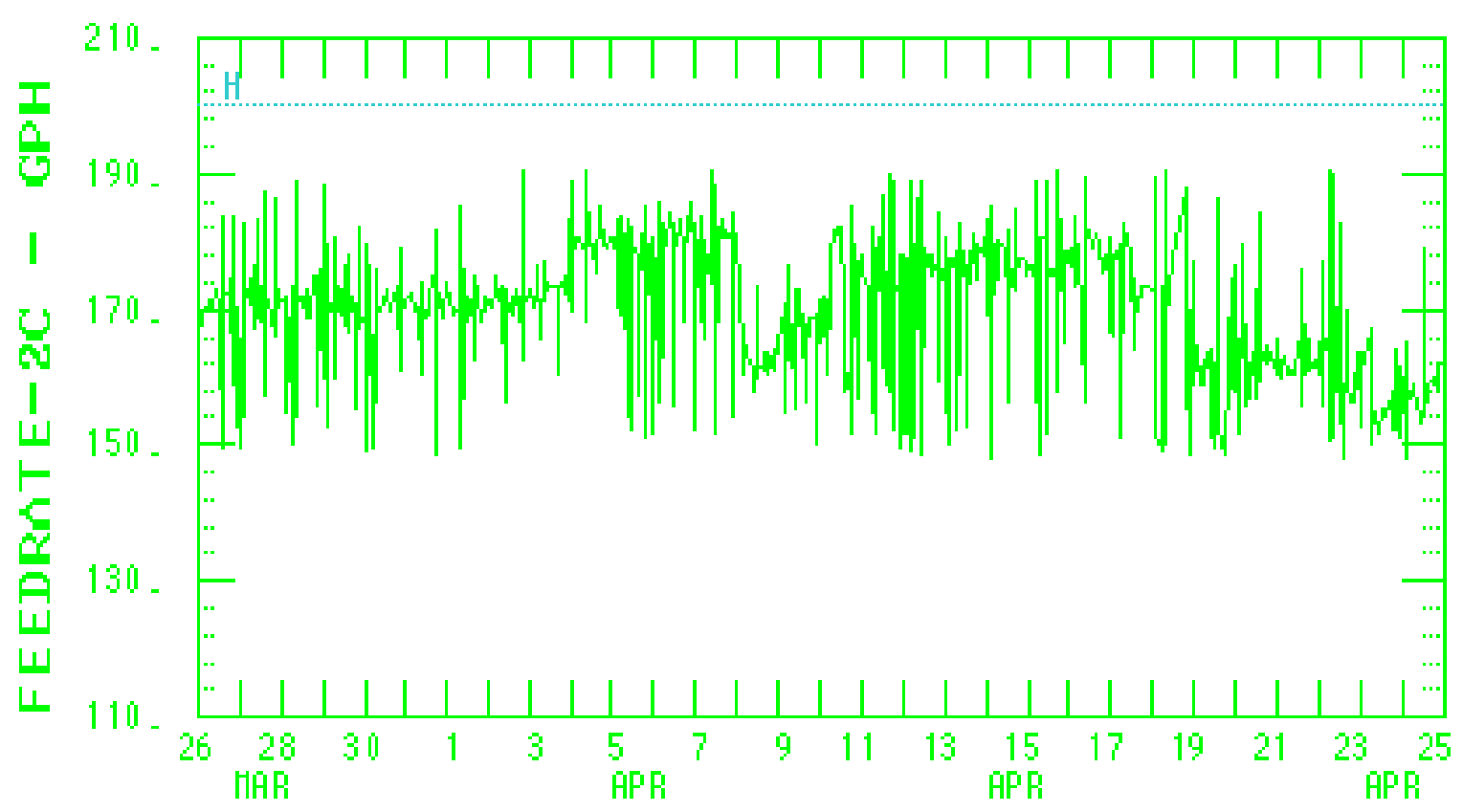

Figure 6. Average Calciner feed rate during March and April 2000.

Figure 6 shows the feed rate met or exceeded the $170 \mathrm{gph}$ criterion for the first three-fourths of the month. During that three-week period, no problems were noted with the kerosene, oxygen, off-gas or any other systems. The feed rate was achieved using all four fuel nozzles, and three of the four feed nozzles. One of the feed nozzles had a leak and was not used during the run. On April 18, the feed rate was lowered to about 160 gph, slightly under the criterion. The feed rate remained at about 160 gph for the remainder of the run. The reason for the drop in feed rate had nothing to do with the operability of any calcining equipment. The feed rate was lowered because the NOx monitor on the INTEC main exhaust stack was recalibrated in mid April, resulting in a slightly increased value of NOx. The Calciner feed rate was lowered slightly to avoid exceeding the stack NOx limit. Lowering the feed rate had nothing to do with the high-temperature flowsheet. The test run met the criterion of demonstrating a minimum feed rate of 170 gph because of the three-week period of successful operation prior to the recalibration of the stack NOx montior.

\subsection{Bed Fluidization}

Criterion 5: Fluidization maintained across the bed as indicated by consistent temperature trends on temperature indicators $\mathrm{T}-105-8, \mathrm{~T}-105-9$, and $\mathrm{T}-105-10$ or temperature differences of no more than $40^{\circ} \mathrm{F}$ between the readings on temperature indicators T-105-8, T-105-9, and T-105-10.

Bed fluidization is an extremely important calcining parameter. One of the characteristics of a wellfluidized bed is efficient and uniform heat transfer throughout the bed. This is most easily observed by comparing the temperatures of the bed in a variety of locations. A well-fluidized bed should have uniform temperatures throughout the bed. In addition, if the bed temperature fluctuates, the various bed temperatures should all fluctuate together. Poor fluidization can result in hot spots in the bed. Such hot spots can sinter the calcine and cause bed agglomeration. Poor fluidization also affects how the waste 
feed is distributed within the bed. Poor feed distribution can result in agglomeration and poor particlesize control, which further adversely affects the quality of bed fluidization. Over the years, poor bed fluidization has caused unscheduled Calciner shutdowns.

The test criterion refers to three temperature monitors (referred in shortened terms to points 8,9 , and 10) located in the Calciner vessel. There are several more temperature monitors in the Calciner vessel, however these three were chosen as the best early indicators of poor bed fluidization. Point 10 is located very low in the Calciner vessel. It is only eight inches above the fluidizing air distributor grid, and below the feed and fuel nozzles. In this location, it is fluidized only by the fluidizing airflow, and not by any vaporized water, atomizing air, products of combustion, etc. Temperature point \#10 will give the first indication of poor fluidization by deviating, often significantly, from the temperatures in the rest of the fluidized bed. Points 9 and 8 are located one and two feet respectively above point 10 in the fluidized bed.

Figure 7 is a one-day plot of data from a previous (July 3, 1993) $500^{\circ} \mathrm{C}$ (graph temperatures are in Fahrenheit) Calciner campaign. It is included to illustrate the difference between well-fluidized and poorly fluidized bed temperatures. Figure 7 shows temperature points 9 and 10, the temperature monitors 20 and 8 inches respectively above the fluidizing air grid, together on the same graph with the same scale. Point 9 is a relatively straight line at $925^{\circ} \mathrm{F}$. However, point 10 "wanders" erratically, at times over $200^{\circ} \mathrm{F}$ lower than point 9 . Such temperature disparities are indications of poor fluidization and poor Calciner operation.

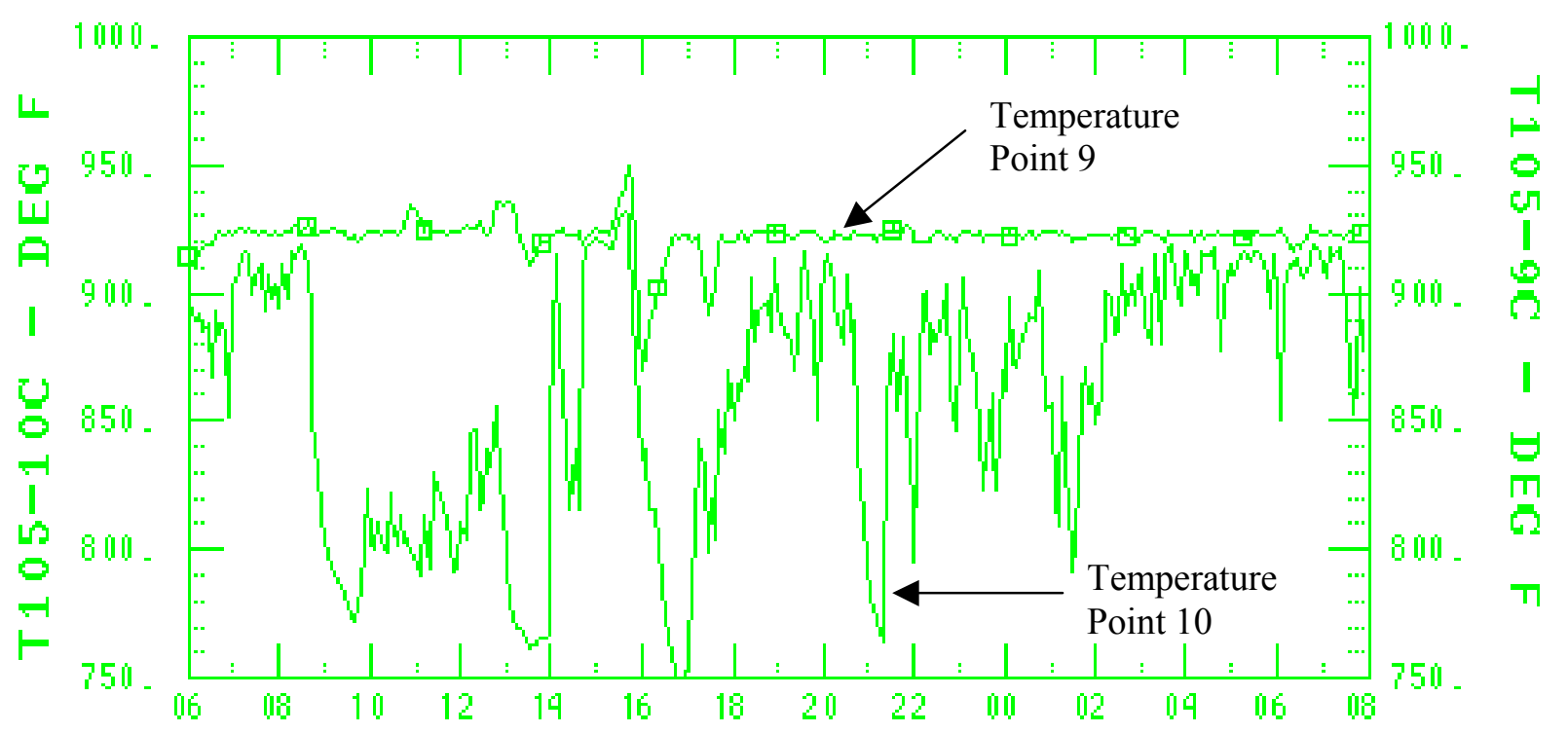

Figure 7. Calciner bed temperature in $1993\left(\right.$ Calciner at $\left.500^{\circ} \mathrm{C}\right)$.

Figure 8 displays bed temperature points 9 and 10 during March and April 2000 including the transition from $500^{\circ} \mathrm{C}$ to $600^{\circ} \mathrm{C}$ on March 25 (graph temperatures are in Fahrenheit). The figure shows the two temperatures track each other very closely at both operating temperatures. The temperatures are so close together they are virtually on top of each other. Bed temperature point 10 does not "wander" or vary from point 9 in the high-temperature run as it did in July 1993 (Figure 7). This indicates excellent bed fluidization. 


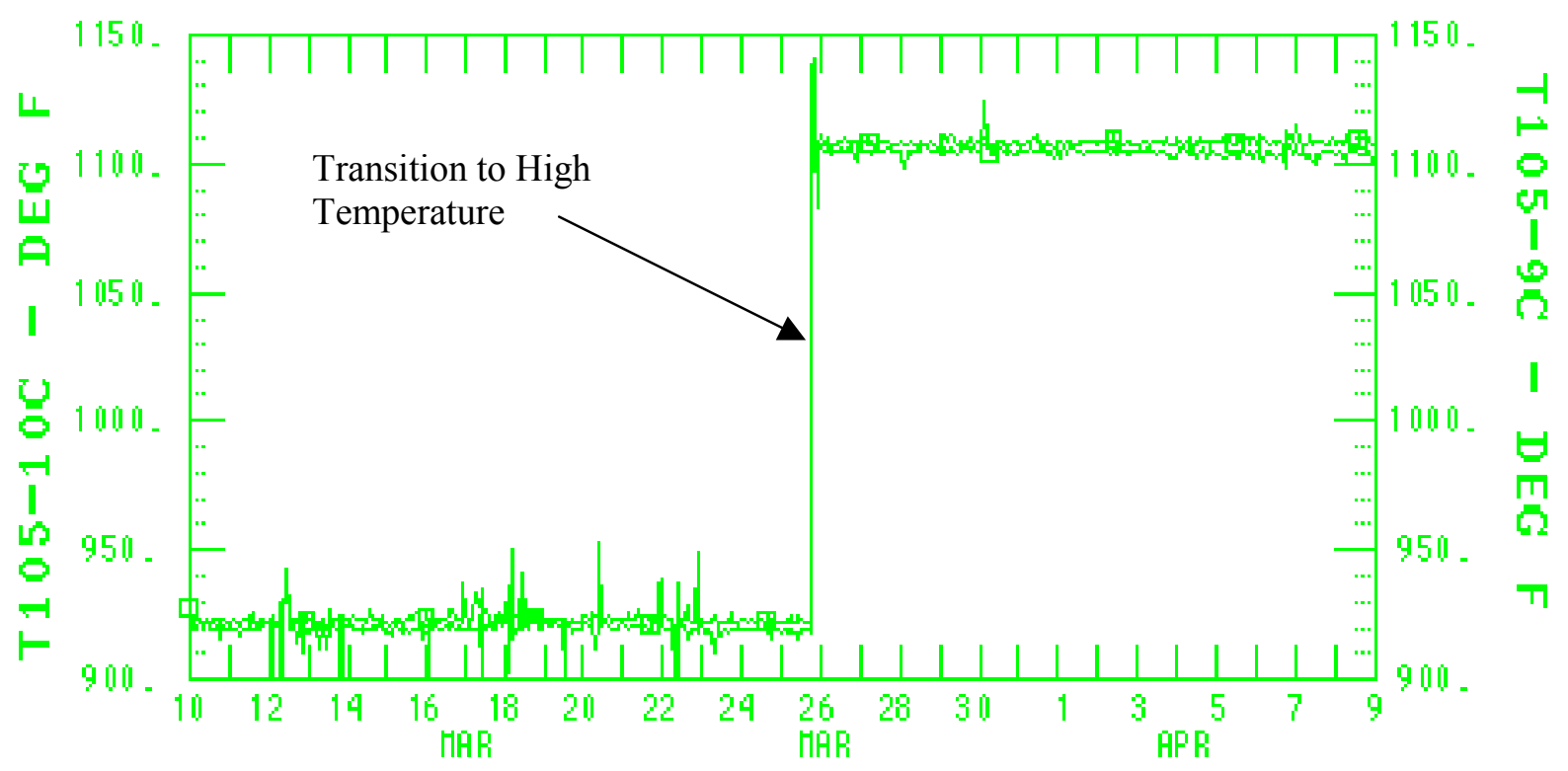

Figure 8. Calciner bed temperatures tracking closely at $500^{\circ} \mathrm{C}$ and $600^{\circ} \mathrm{C}$.

Figure 9 shows bed temperature points 8 and 10 during the high-temperature operation. Figure 9 shows the two temperatures to consistently be within about ten degrees $\mathrm{F}$ of each other. The bed temperatures easily met the test criterion of being within $40^{\circ} \mathrm{F}$ of each other.

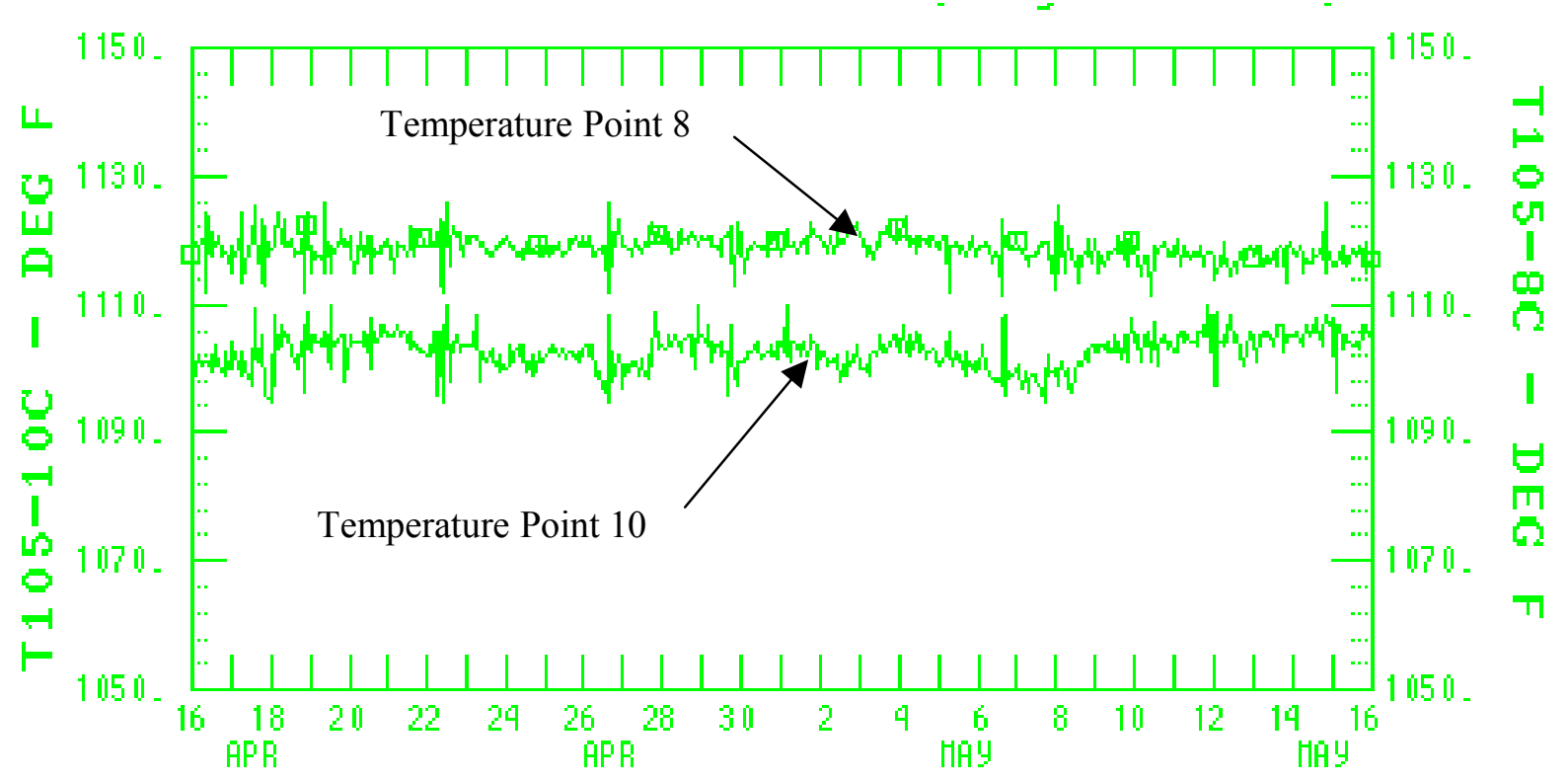

Figure 9. Calciner bed temperatures showing good correlation at $600^{\circ} \mathrm{C}$. 
Part of the bed fluidization criterion is to have consistent temperature trends between the temperature monitors. Figure 10 illustrates this occurred during the high-temperature run. Figure 10 shows temperature data on April 13, 2000 during a minor process upset (change in feed rate) which resulted in a minor temperature fluctuation. Both bed temperatures track downward and then upward in unison, indicating excellent bed fluidization. The bed temperatures met the criterion for closely tracking each other.

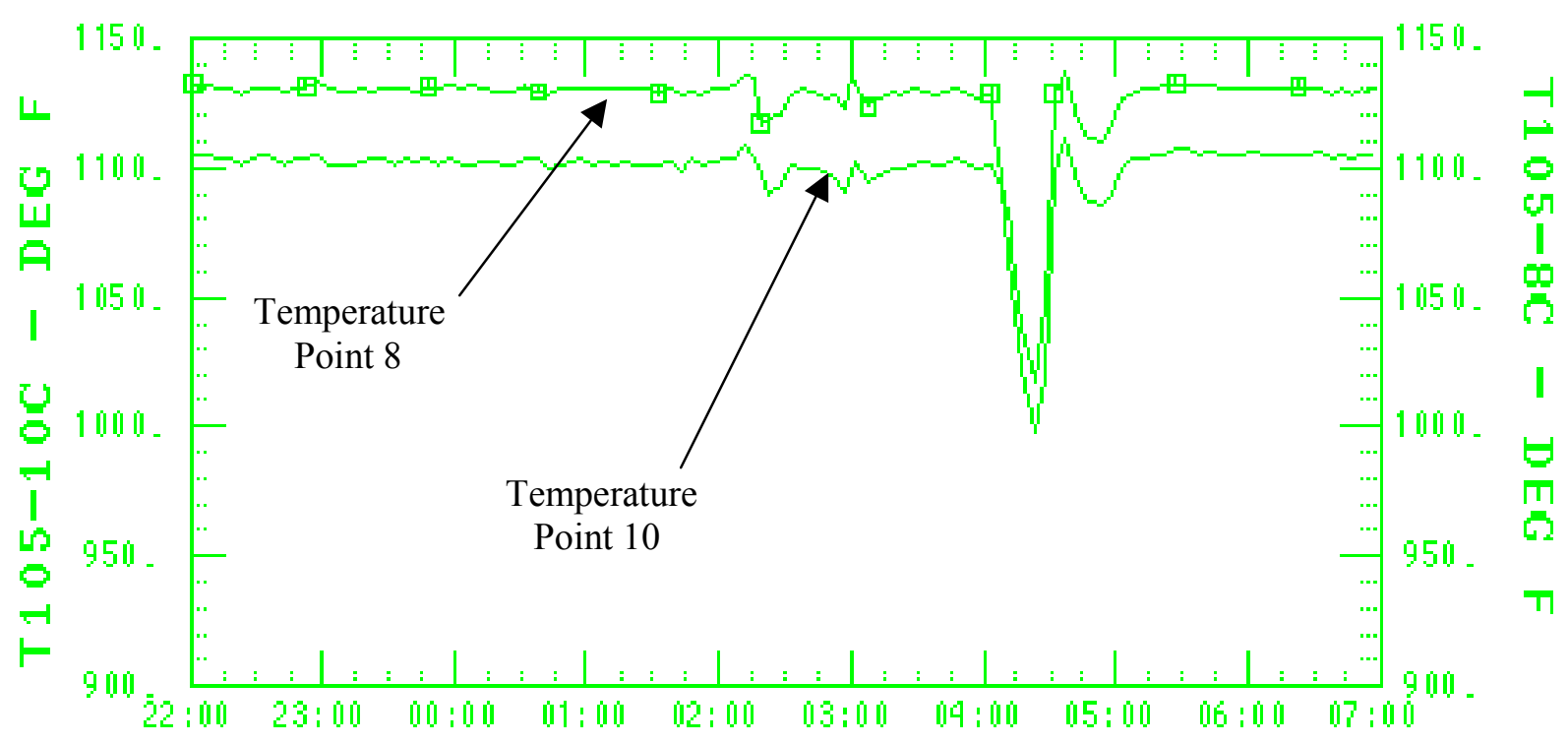

Figure 10. Calciner bed temperatures during a temperature oscillation (Calciner at $600^{\circ} \mathrm{C}$ ).

\subsection{Product Size}

Criterion 6: Product size (MMPD) controlled between $0.25 \mathrm{~mm}$ and $0.60 \mathrm{~mm}$ for each feed blend ratio by adjusting the nozzle air ratio (NAR). NAR maintained below 450 during high-temperature operation.

The size of the calcine particles in the fluidized bed is an important parameter. The particle size is directly related to the quality of bed fluidization. Very small particles are blown out of the bed and into the off-gas system with the fluidizing air, water vapor, and combustion products. This can overload the off-gas system, resulting in off-gas system plugging, high quench solution recycle rates, and low net feed rates. On the other hand, if the particles get too large, they are difficult to fluidize with the existing fluidizing air blowers. Very large particles will fall to the bottom of the Calciner and create an unfluidized zone, characterized by large temperature gradients through the bed.

During normal operation, the Calciner bed particle size reaches a dynamic equilibrium. The bed particles grow larger as they are coated with feed material. Simultaneously, they grow smaller as the agitation and grinding action within the bed breaks up larger particles. Samples of the bed are periodically taken and analyzed for to determine average particle size. The average particle size is the mass-mean particle diameter (MMPD). 
Based on the results of the sample analysis, several operating parameters can be adjusted to increase or decrease the particle size. The particle size is strongly influenced by the Calciner flowsheet and the chemistry of the feed solution. Some chemicals generate very hard calcine that tends to grow into large particles because it breaks up into smaller pieces very slowly. Conversely, other chemicals make soft calcine that is easily broken up into smaller particles. Changing the feed blend can change the particle size. The high-temperature flowsheet is a significant change to the Calciner operation. In order to increase the net waste-processing rate, the amount of sodium in the feed is significantly increased over that of historical waste feeds. In addition, the high-temperature flowsheet generates different solids (sodium aluminates instead of nitrates) with different characteristics. The high-temperature flowsheet calcine will have particle size characteristics different from that of historical flowsheets.

The operating parameter most often used to control the particle size is the amount of air used to atomize the waste feed. This parameter is often referred to as the nozzle-air-ratio, or NAR. Increasing the NAR (by increasing the atomizing airflow) tends to result in smaller calcine particles. At high NAR values, the atomizing air produces very fine droplets of waste. Many of these fine droplets are "spray dried" in the Calciner vessel and form very small particles instead of coating existing particles to make larger particles. The energy of the increased airflow going into the bed also tends to break up the bed particles as they move around in the fluidized bed. A high NAR may make too many very fine particles that can be blown out of the bed and adversely affect the off-gas system.

Operating personnel took bed samples and measured the particle size twice a day during the hightemperature run. Some data scatter with the particle size occurred, as there were some difficulties associated with new particle-size analysis equipment. Figure 11 shows the average particle size (MMPD) for the entire 2000 operation.

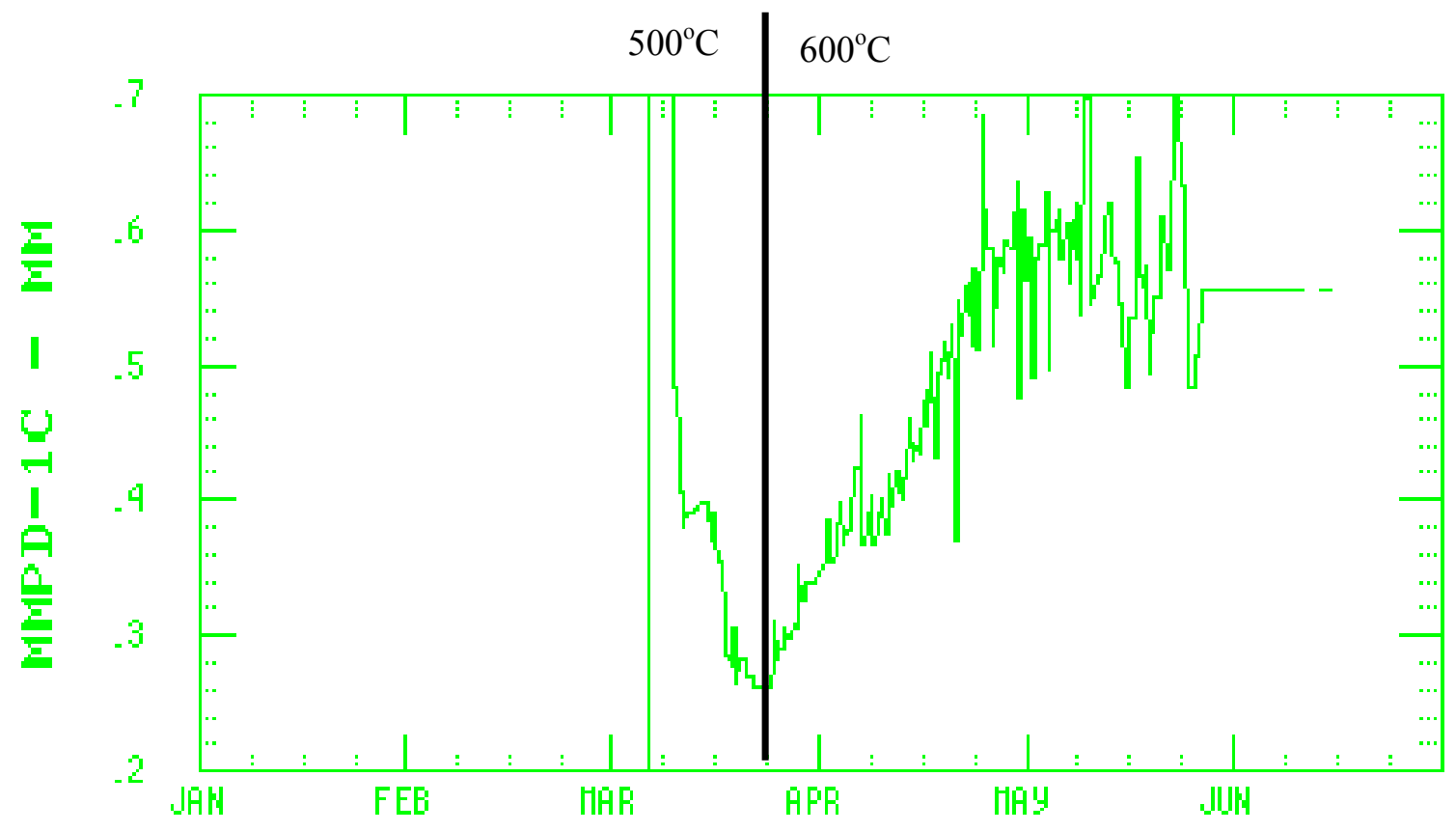

Figure 11. Plot of calcine particle size (MMPD) during Calciner operation in 2000.

The data at the start of the run in early March is off the high end of the scale and represents the relatively large dolomite material used as the start-up bed. The figure shows the particle size rapidly decreased to about $0.26 \mathrm{~mm}$ by late March. This was the condition of the bed when the high-temperature test began on 
March 25. The figure shows the particle size then steadily increased in size until it stabilized at about $0.58 \mathrm{~mm}$ in late April. The particle sized remained at that value for the next month until the Calciner was shut down. Figure 11 shows the particle size met the criteria for being stable and between 0.25 and 0.60 $\mathrm{mm}$ for high temperature operation.

During the high-temperature test, some personnel expressed concern because the particle size was near the upper end of the criterion range. The criterion range was selected based on historical Calciner operation with SBW at $500^{\circ} \mathrm{C}$. Calcining SBW at $500^{\circ} \mathrm{C}$ created "sticky", irregularly shaped, agglomerate-prone, bed particles. Such particles had to be kept small in order to maintain good bedfluidization characteristics and prevent agglomeration. The high-temperature bed particles were not "sticky" or irregularly shaped as past SBW blends have been. They were not agglomeration prone, and bed fluidization characteristics were excellent. It is likely even larger particle sizes would have resulted in stable operating conditions. Operating data from the original Waste Calcining Facility (WCF) supports this conclusion. In the first three operating campaigns at $\mathrm{WCF}$, the particle size (mmpd) ranged from 0.6 to $1.0 \mathrm{~mm}$ with stable operation and no bed agglomeration problems. Those three campaigns did not use the in-bed-combustion system and did not calcine any SBW.

Part of the particle size criterion was to control the particle size with a NAR of less than 450 . Figure 12 shows the average value of the NAR for the three feed nozzles in use for the Calciner operation in 2000.

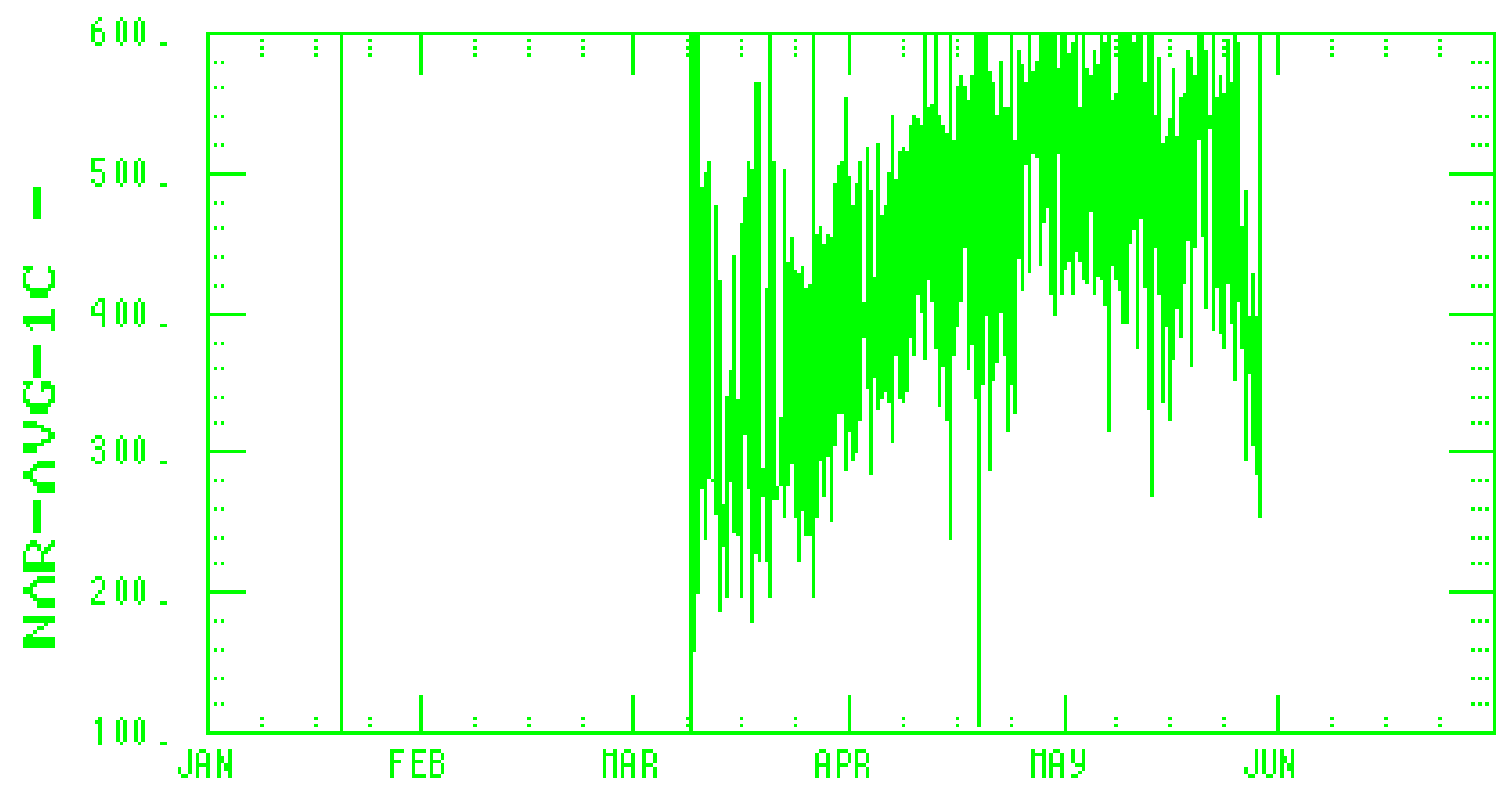

Figure 12. Calciner feed system nozzle air ratio (NAR) during 2000.

The NAR data trend is very similar to that of the particle size (Figure 11). The NAR began at about 300 in March, and then slowly increased to about 525 by the end of April. It remained near 500 for the duration of the high-temperature test. Operating personnel increased the NAR during April to control the particle size, which was increasing. Increases in the NAR stopped when the particle size became stable. Although the NAR went above the criterion value of 450, Calciner operation was judged acceptable at the elevated value. The criterion was based on past $\left(500^{\circ} \mathrm{C}\right)$ operating experience. The reason for the upper NAR limit is to prevent significant amounts of "spray drying". This is characterized by the inability to build bed in the Calciner because of the loss of so much bed being blown out of the Calciner. Bed level data show spray drying was not a problem during high-temperature operation. Figure 13 shows the 
Calciner bed level for a typical five-day operation period in early May when the NAR was at the maximum value of 525. The jagged, saw-toothed data plot shows the bed level increased and decreased at regular intervals and rates. The bed increase meant excessive spray drying and subsequent fines carryover did not occur, otherwise no bed increase would have occurred. The bed decrease occurred when operating personnel removed product from the Calciner and sent it to calcine storage in order to maintain the bed level in its proper range.

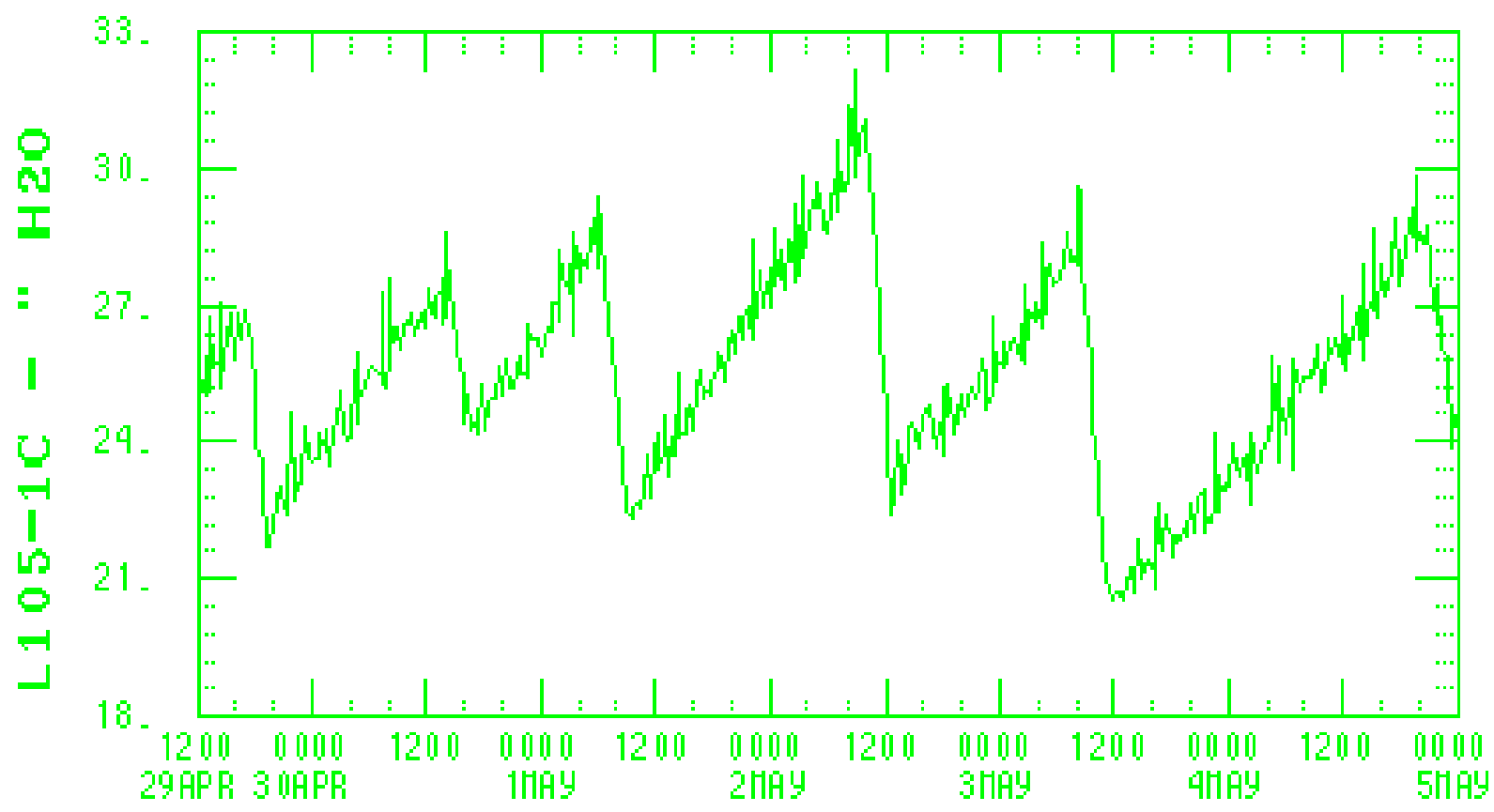

Figure 13. Bed level in the Calciner showing normal bed growth and removal in May 2000.

The criterion limit of 450 for the NAR is near the upper value that can be measured for that parameter if only three feed nozzles are used for calcining. One of the four nozzles is frequently unavailable for use due to system plugs, leaks, etc. NAR values much above 500 reach the upper end of the atomizing airflow instrumentation for only three nozzles at full waste processing rates. Higher values of NAR can be achieved by using four feed nozzles instead of three. This distributes the flow of waste between four instead of three nozzles, effectively increasing the potential atomizing airflow by thirty-three percent, and the NAR to about 650 .

Although the NAR slightly exceeded its criterion, there were no negative impacts (such as excessive fines carryover) and thus the test is considered successful. The test demonstrated the high-temperature flowsheet is not as prone to excessive fines generation and carryover at high NAR values as some past Calciner flowsheets have been. The test also demonstrated stable operation with particle sizes at the upper end of the NWCF Calciner historical operating range. Stable operation with even larger particle sizes is likely possible based on WCF experience.

\subsection{Stable Fines Column Operation}

Criterion 7: Stable fines column operation demonstrated by maintaining a level of 25-175 inches on level indicator L107-1C and by a lack of plugging or bridging that cannot be corrected by normal column air blasting procedures. 
The fines column is a solids disengaging leg located on the discharge of the fines removal cyclone (VESNCC-107). It consists of a twenty-foot section of six-inch pipe and normally contains a level of fine particles in it. Fines enter the top of the column from the cyclone and exit the bottom through a throttling valve. The throttling valve is periodically adjusted in order to maintain the level of fines within a prescribed range. The purpose of the fines column is to provide a physical barrier between the wet Calciner offgas and the dry pneumatic transport system and calcine storage facility. This prevents moist Calciner offgas from entering the solids transport system, where it could condense and contribute to transport line-plugging problems.

The fines column level is normally at the lower end of its acceptable range of 25 to 175 inches. A level below 25 inches may be insufficient to maintain the pressure boundary between the Calciner off-gas system and the transport system. A level above 175 inches approaches the point where the fines column is full. At that point, fines will be carried through the cyclone and into the quench system, potentially overloading that system.

Figure 14 shows the fines column level for a one-month period from mid March to mid April. This period covers the transition from $500^{\circ} \mathrm{C}$ to $600^{\circ} \mathrm{C}$ that occurred on March 25. A flow-sheet transition period is the time in which most fines are generated in the Calciner. Problems with fines carryover and fines column control typically occur during a flowsheet transition. Figure 13 shows the fines column level behaved the same before and after the transition on March 25. The fines level was within the criterion range at both operating temperatures. The fines column level remained in the criterion range for the duration the high-temperature test. No significant fines column plugging or bridging occurred. The fines column met its criteria for level control.

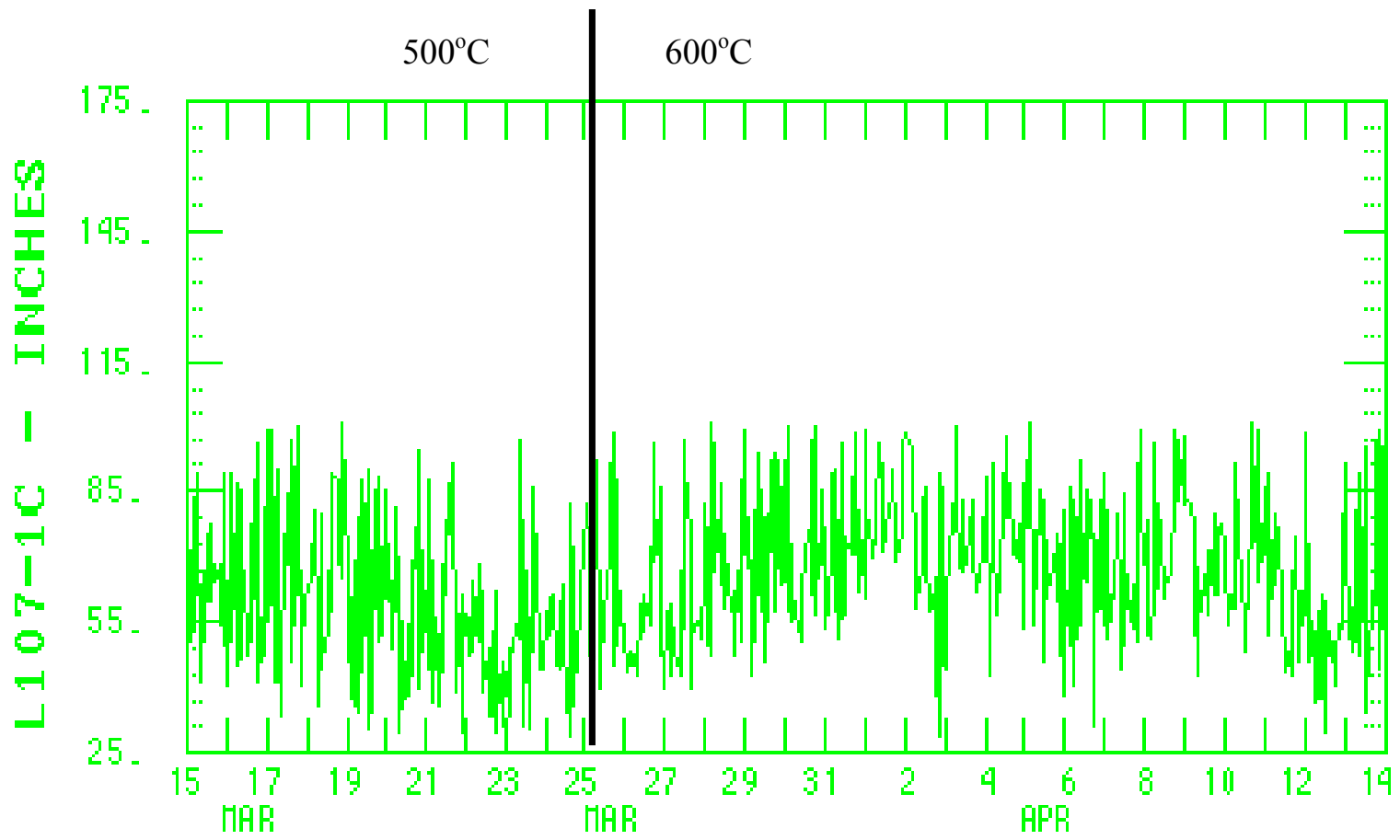

Figure 14. Fines column level before and after the high-temperature transition on March 25, 2000. 


\subsection{Scrub Solution Recycle Rate}

Criterion 8: The scrubbing solution recycle rate maintained at less than $20 \%$.

During Calciner operation a portion of the fines blown out of the bed make it through the cyclone and are removed in the wet scrubbing system (quench tower and venturi scrubber). Nitric acid is continuously added to the quench solution to dissolve the fine calcine in the quench solution. Samples of the quench solution are routinely analyzed for both dissolved and undissolved solids (UDS). These samples help operations personnel determine the proper amount of acid to add to the quench system. The additional quench solution generated by the addition of acid and dissolution of solids is periodically recycled back into the feed system. Large amounts of fines in the quench solution require more acid to dissolve them. This generates larger amount of quench solution that must be recycled. Large recycle volumes reduce the amount of Tank Farm waste in each feed batch, reducing the net processing rate of SBW. In order to maximize the amount of waste processed, a low recycle rate is desirable.

Figure 15 is a graph of the scrub build-up rate in the quench hold tank during the last month (May) of high temperature operation. The scrub build-up rate is normally the same as the recycle rate. This is because all of the increase in scrub solution (scrub buildup) must eventually be recycled into the feed hold tanks. A statistical application has been applied to the data in Figure 15 to calculate the average (mean) scrub build-up rate of $32 \mathrm{gph}$. This value is shown as a dashed horizontal line through the data. The box in the lower right-hand corner of the graph contains the numerical value of the mean ( $32 \mathrm{gph})$. During the high-temperature operation, the feed rate varied from 150 to $175 \mathrm{gph}$.

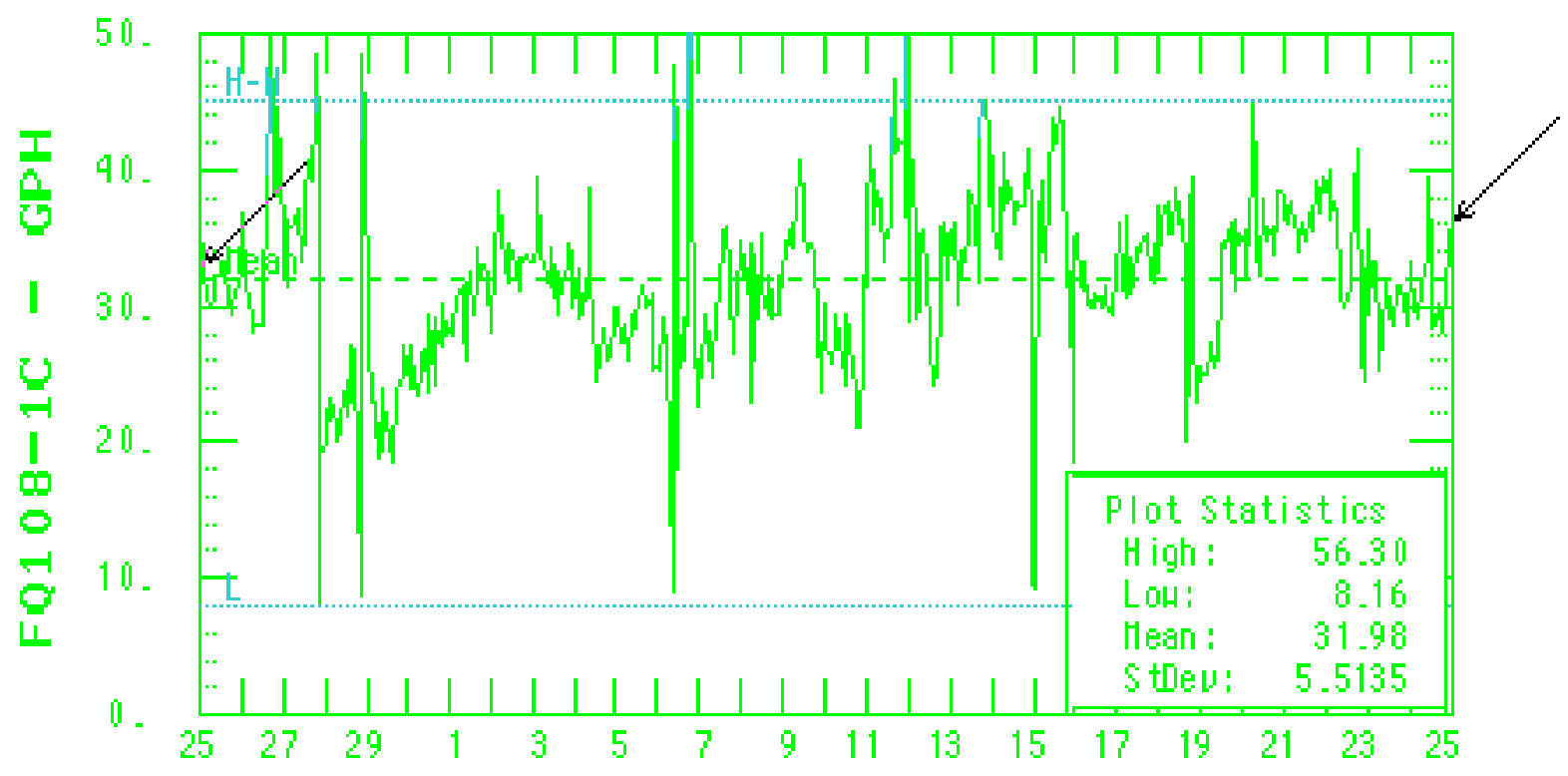

Figure 15. High-temperature scrub build-up rate (average 32 gph) during May 2000.

Figure 16 shows the feed rate for the entire 2000 operation. The statistical analysis of the hightemperature portion of the data shows an average feed rate of $159 \mathrm{gph}$. A scrub build-up rate of $32 \mathrm{gph}$ and a gross feed rate of 159 gph result in a recycle rate of $20 \%$. This scrub recycle value met the hightemperature criteria of $20 \%$. 


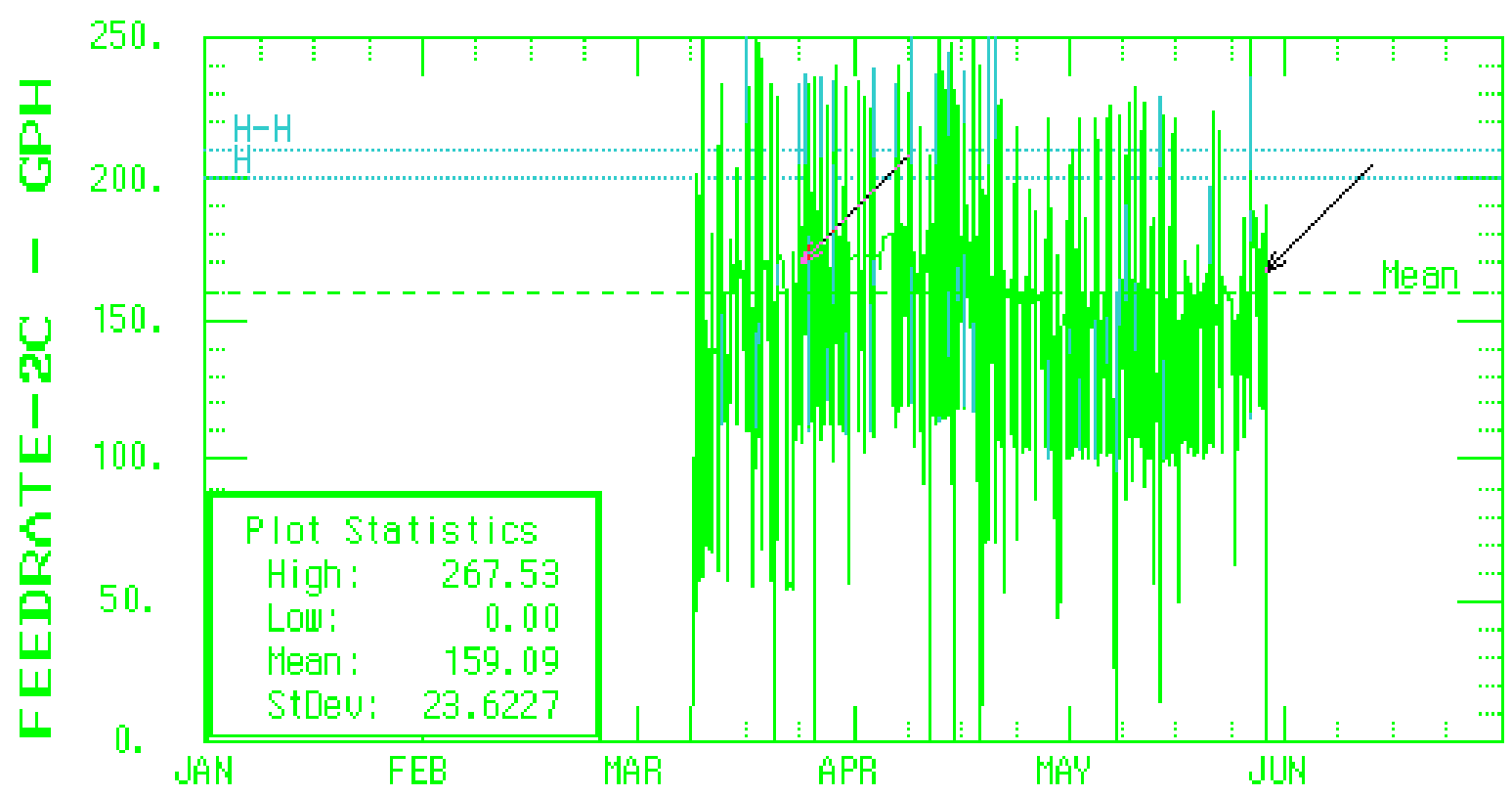

Figure 16. High-temperature Calciner feed rate (average $159 \mathrm{gph}$ ) during 2000.

The preceding discussion concluded the scrub recycle met the criterion value of $20 \%$. If one uses the feed make-up sheets and calculates the total amount of scrub and of feed solution, a value slightly higher than $20 \%$ is obtained. This is because the scrub solution was transferred to the feed system via an alternate path due to an inoperable valve on the normal path. The normal transfer route is a slipstream from the quench pump discharge directly to the feed hold tanks. An in-cell valve on that transfer route was inoperable, and so scrub solution was jetted from the scrub hold tank to the hot sump tank (VES-NCC119), and from there it was jetted to the feed hold tanks. Steam jets, with the accompanying jet dilution, provided the motive force for each of these two transfers. Two steam jet dilutions at $5 \%$ each make a total jet dilution of about $10 \%$. Thus, instead of $20 \%$ scrub recycle, the feed makeup sheets show about $10 \%$ extra or about $22 \%$ recycle. The inoperable valve had nothing to do the high-temperature operation and the extra transfers and jet dilution occurred at both operating temperatures.

\subsection{Venturi Scrubber Pressure Drop}

Criterion 9: A pressure drop of at least 50 inches of water maintained through the venturi scrubber.

The venturi scrubber is a significant component in the off-gas treatment system. Its primary purpose is to remove micron-sized particles of calcine that are too small to be removed by the upstream cyclone. The scrubber is a venturi into which scrub solution is sprayed. The throat of the scrubber has an adjustable orifice that can be opened or closed, depending on the air flow rate, to maintain a given differential pressure across the scrubber. Vendor data and test results indicate the solids removal efficiency of the scrubber to be proportional to the pressure drop across the scrubber. Higher pressure drops result in higher particulate removal efficiencies. The high-temperature flowsheet generates higher off-gas flows. Higher gas flows result in higher pressure drops through the off-gas system. If the off-gas system were unable to handle the additional gas flow, one way of compensating would be to lower the pressure drop across the venturi scrubber, which is a significant portion of the total off-gas pressure drop. Lowering the venturi scrubber pressure drop could adversely affect its solids removal efficiency. This could contribute 
to plugging or increased pressure drop in downstream equipment such as the ruthenium adsorbers and HEPA filters.

Figure 17 shows the venturi scrubber pressure drop for a typical 30-day period during the hightemperature run. Normal operation is between 50 and 60 inches of water.

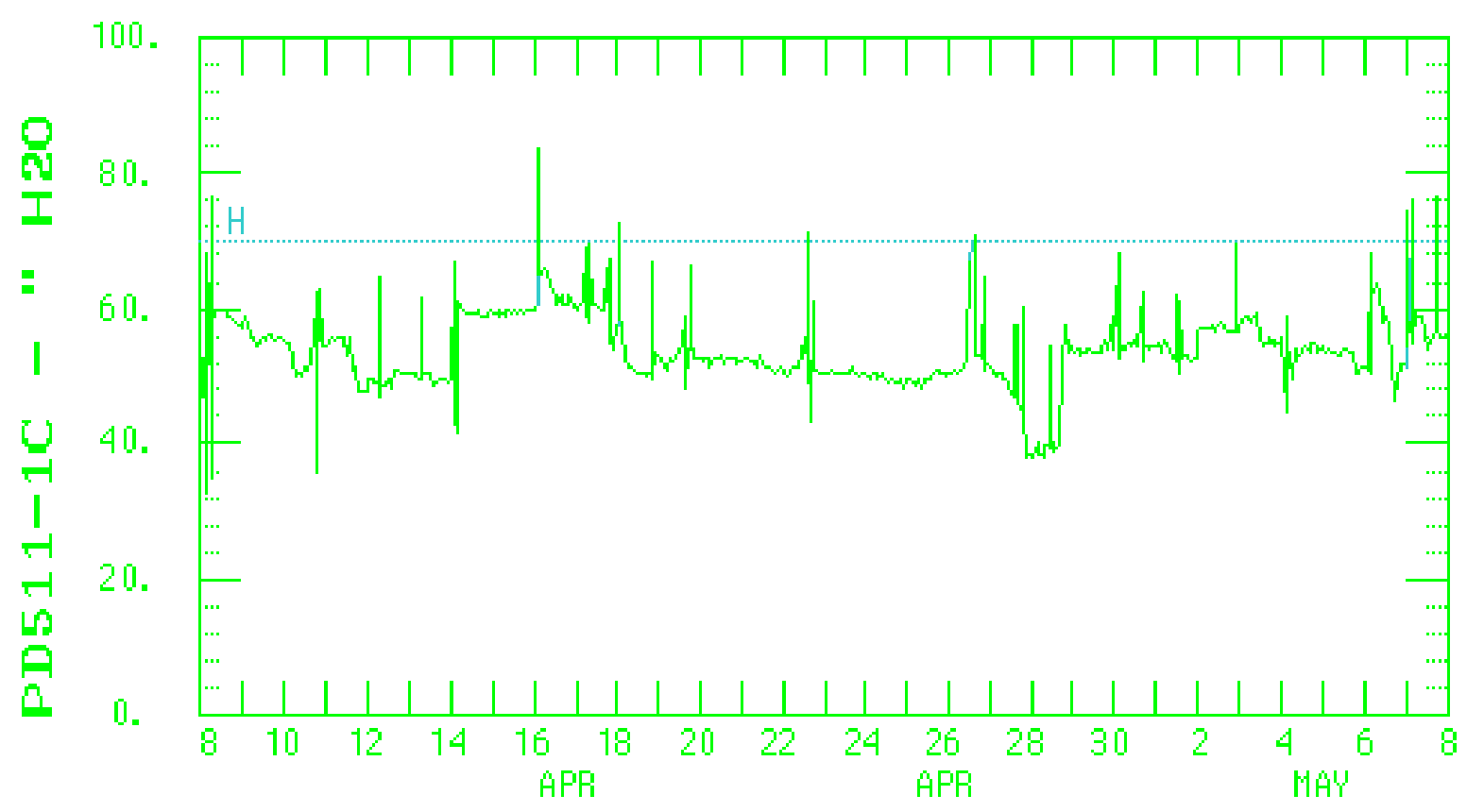

Figure 17. Venturi scrubber pressure drop during April 2000 high-temperature operation.

Figure 17 shows the high-temperature value for the venturi pressure drop was in the normal range, and at least above 50 inches of water. The one exception occurred on April 28 when the pressure drop went to about 40 inches of water. The reason for the drop was a restriction in the off-gas superheater (HE-NCC335). Occasional restrictions in the superheater are normal for the Calciner, even at $500^{\circ} \mathrm{C}$. The pressure drop across the venturi scrubber was restored when the superheater was flushed using standard operating procedures. There were no problems with downstream equipment to indicate any particulate removal problems with the venturi scrubber. The venturi scrubber pressure drop met its criterion.

\subsection{Scrub Solution Undissolved Solids (UDS)}

Criterion 10: The scrubbing solution undissolved solids concentration maintained at less than 15 $\mathrm{g} / \mathrm{L}$.

Scrub (quench) solution chemistry is an important parameter in the calcination process. The scrub solution is composed of acid, water, and fine (micron sized) calcine particles removed from the offgas in the wet scrubbing system. Nitric acid is continuously added to the scrub solution to dissolve the fine calcine particles. Calcine that does not dissolve is present as undissolved solids (UDS). Maintaining a low level of UDS is important because it means several Calciner flowsheet parameters are under control. 
One potential cause of high UDS is the feed and calcination chemistry. From the initial days of calcination, the formation of insoluble alumina (alpha phase) has been a concern. Insoluble alpha alumina is highly erosive to quench system components such as valves, piping, pumps, spray nozzles, etc. In addition, if the solids are insoluble, they build up until the system is so solids laden it turns into a slurry. The slurry plugs lines, valves, nozzles, etc. Eventually, the formation of large quantities of alpha alumina will cause a Calciner shutdown due to quench system failure.

Another cause of high UDS is the generation of such large quantities of fine particles in the Calciner that the off-gas system becomes overloaded with fines. In such cases, increasing the flow of acid to the quench solution hold tank may dissolve the excess solids. However, a high acid flow creates more quench solution which must be recycled back into the feed system. Large quantities of quench recycle significantly lower the net feed rate to the Calciner and make the Calciner inefficient. A similar situation could exist if upstream fines removal equipment (cyclone and tall fines column), are inefficient, plugged, or in some way operating inefficiently.

The UDS criterion of less than $15 \mathrm{~g} / \mathrm{L}$ is actually quite restrictive based on Calciner operating history. UDS values at the criterion level have been achieved only during recent SBW processing. Historically, when processing zirconium fluoride wastes containing calcium nitrate, the quench solution UDS values ranged from 10 to $50 \mathrm{~g} / \mathrm{L}$ on average, and even higher during upsets and flowsheet transitions.

During the high-temperature operation, quench solution samples were taken on a daily basis. Figure 18 shows the amount of UDS in the quench solution during high-temperature operation.

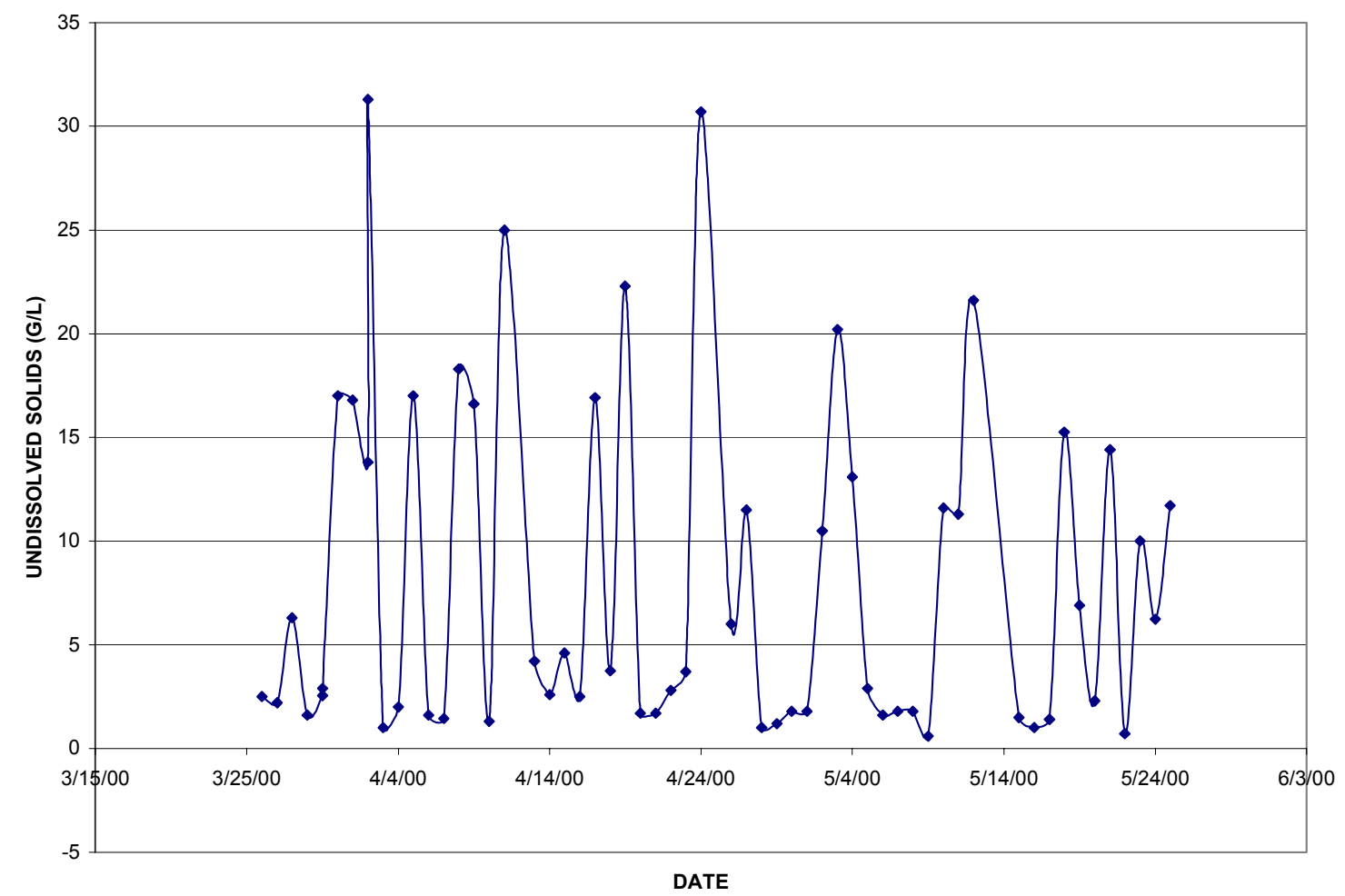

Figure 18. Undissolved solids in the quench solution during the 2000 high-temperature operation. 
There is considerable data scatter between some of the samples on Figure 18. This is consistent with historical quench solution UDS sample results. Calciner operating conditions at the time of the sample can explain much of the data scatter, especially the upward spikes. For example, the highest UDS value on Figure 18 is $31 \mathrm{~g} / \mathrm{L}$ and occurs on April 2. Operations "blasted" the fines column on that date. Blasting the fines column is the term given to the procedure used to periodically remove restrictions from the fines column. The fines column contains very fine (flour-like) calcine solids. Occasionally those solids pack together in such a manner that they no longer flow freely through the column. At that point the column is plugged and solids entering the cyclone can not be removed and will be carried by the offgas into the quench system. Operations personnel inject (blast) air into the fines column to loosen and dislodge the packed solids. This restores the flow of solids out of the column. The injection of air blows some of the solids out of the column and into the quench system. Such operations result in temporary, above-normal UDS values. After the sample on April 2, the next two (April 3 and 4) UDS values on Figure 18 are very low (less than $5 \mathrm{~g} / \mathrm{L}$ ). The return to low UDS values after the spike is an excellent trend. It means the solids are not insoluble alpha alumina. Also, the off-gas and quench systems are not overloaded with fines. Otherwise, the UDS value would not have recovered so quickly from the high value on April 2.

The UDS data for the high-temperature test appear to have a very low ( 2 to $3 \mathrm{~g} / \mathrm{L}$ ) equilibrium value interspersed with occasional spikes of 15 to $25 \mathrm{~g} / \mathrm{L}$. The overall average of the UDS values on Figure 18 is $7.9 \mathrm{~g} / \mathrm{L}$. This is well within the high-temperature test criterion of less than $15 \mathrm{~g} / \mathrm{L}$. A small number of the samples exceed the criterion value of $15 \mathrm{~g} / \mathrm{L}$, nine of the 63 sample values are between 15 and $20 \mathrm{~g} / \mathrm{L}$, and only six exceed $20 \mathrm{~g} / \mathrm{L}$. There appear to be no adverse long-term trends associated with the UDS sample data, such as slow steady increases in the UDS, steady increases in the amount of quench solution recycled to the Calciner feed system, etc. The UDS data met the specified test criterion.

\subsection{Scrub Solution Chemical Concentration}

Criterion 11: The chloride concentration $(<5000 \mu \mathrm{g} / \mathrm{mL})$, acid normality $(>0.5 \underline{\mathrm{M}})$, and specific gravity $(<1.4)$ of the scrubbing solution maintained within limits using only means normally employed when operating at $500^{\circ} \mathrm{C}$.

As discussed with criterion 10, quench solution chemistry is an important Calciner parameter. The chloride concentration is important from a corrosion aspect. High chloride concentrations can increase the potential of certain types of corrosion (stress corrosion cracking for example). A portion of the chemicals present in the waste feed end up in the quench solution as fine calcine is removed from the Calciner offgas and dissolved in the quench solution. However, some chemicals in the quench solution are present in quantities far larger than that attributed to dissolved calcine. Such chemicals are volatile and leave the Calciner and are condensed in the quench system where they accumulated. Chloride is semi volatile in the Calciner and has historically built up in the quench solution to concentrations far greater than that in the feed solution. Calciner corrosion studies have established acceptable values of chloride in the quench solution. Those studies are the basis of the criterion value of $5000 \mu \mathrm{g} / \mathrm{mL}(\mathrm{mg} / \mathrm{L})$. Figure 19 shows the chloride concentration in the scrub solution during the entire 2000 operation. 


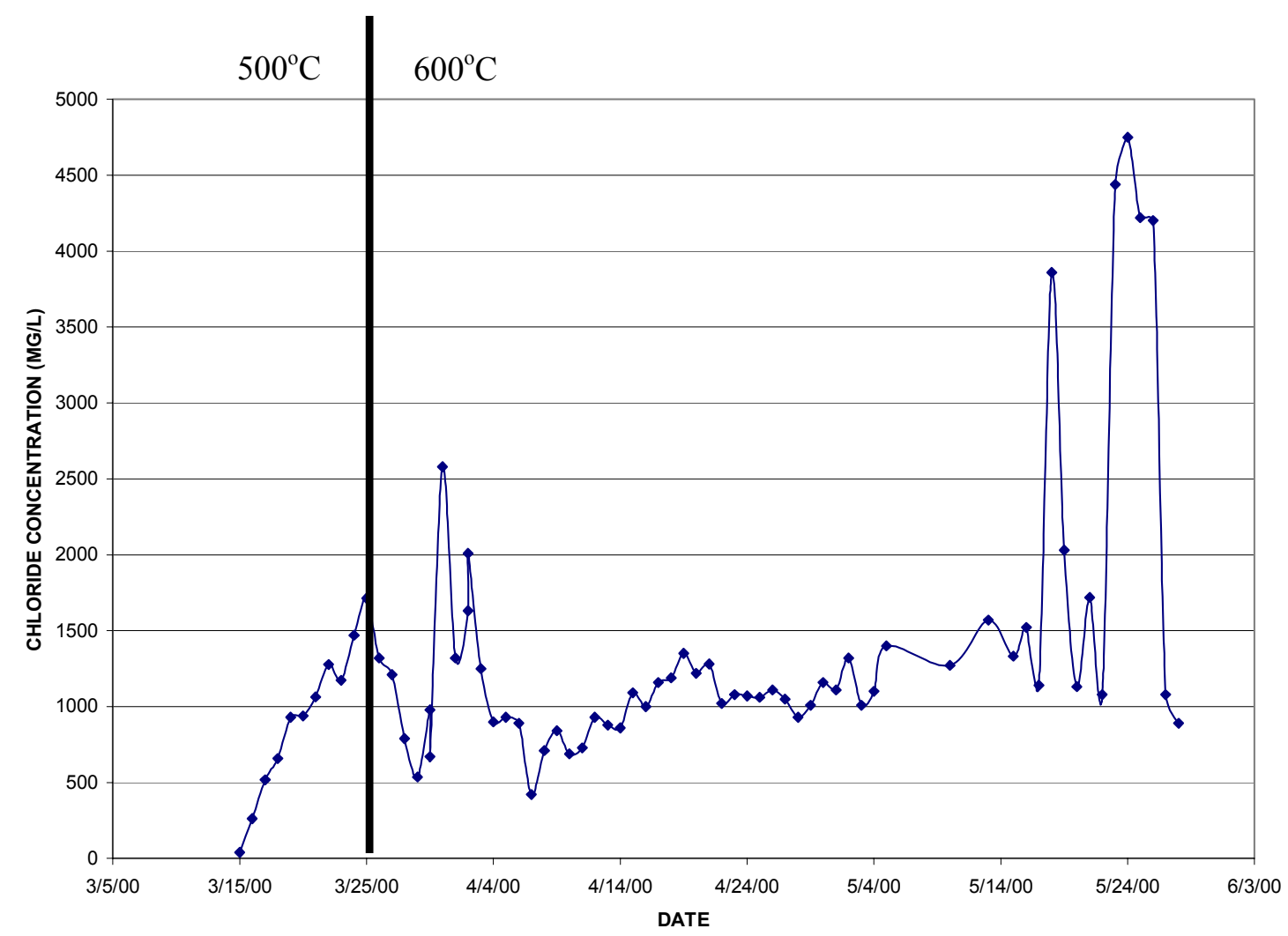

Figure 19. Chloride concentration in the quench solution during the 2000 Calciner operation.

Figure 19 shows all of the chloride sample data were within the acceptable criterion range of less than $5000 \mathrm{mg} / \mathrm{L}$. The chloride began near zero (the initial quench solution was acid with no significant amounts of chloride) and increased rapidly until March 25 when high-temperature operation began. It then stabilized in the range of 1000 to $1500 \mathrm{mg} / \mathrm{L}$. It remained there until the end of May when there were several values of approximately $4000 \mathrm{mg} / \mathrm{L}$. The value then returned to the normal 1000 to 1500 $\mathrm{mg} / \mathrm{L}$ range. The reason for the values of $4000 \mathrm{mg} / \mathrm{L}$ is not known. Those data points appear to be invalid. There were no process changes that can explain the data. Some of the high chloride data occurred during nonradioactive feed processing. Nonradioactive feed should have had low chloride concentrations in the scrub because there would have been little chloride in the feed. The invalid data assumption is supported by independent sample data from the hot sump tank. During Calciner operation, quench solution could not be recycled directly to the feed hold tanks due to a broken valve in the transfer line. Instead, quench solution was first transferred to a hot sump tank (VES-NCC-119), and from there to the feed hold tanks. Quench solution accounted for virtually all of the waste transferred to the hot sump tank. Because the solution in the sump tank came from the quench tank, the sump tank sample results were similar to those of the quench solution. On May 29, after receiving several transfers of quench solution having $4000 \mathrm{mg} / \mathrm{L}$ chloride (per the data on Figure 19), the sump tank was sampled. The sump tank chloride analysis was $1240 \mathrm{mg} / \mathrm{L}$, the same as the two-month long quench tank average. The sump tank chloride level should have been close to $4000 \mathrm{mg} / \mathrm{L}$, had the $4000 \mathrm{mg} / \mathrm{L}$ chloride quench solution samples been valid. This supports the assumption that the quench solution chloride values of $4000 \mathrm{mg} / \mathrm{L}$ were invalid. The quench solution chloride concentration met the test criterion of less than $5000 \mathrm{mg} / \mathrm{L}$.

Acid concentration (normality) is used, along with UDS, as an indication that solids in the quench solution are under control. Nitric acid is continuously added to the quench solution to dissolve solids (fine calcine) removed from the off-gas system. Dissolution of the solids depletes the acid. Stable 
operation is achieved when the addition rate of fresh acid and the acid depletion rate are the same. This results in low values of UDS and stable values of acid concentration. A low acid concentration (less than 0.5 normal) indicates too many solids are entering the off-gas and scrub system, or too little acid is being added to the quench system. Figure 20 shows the quench solution acid concentration during the entire 2000 operation.

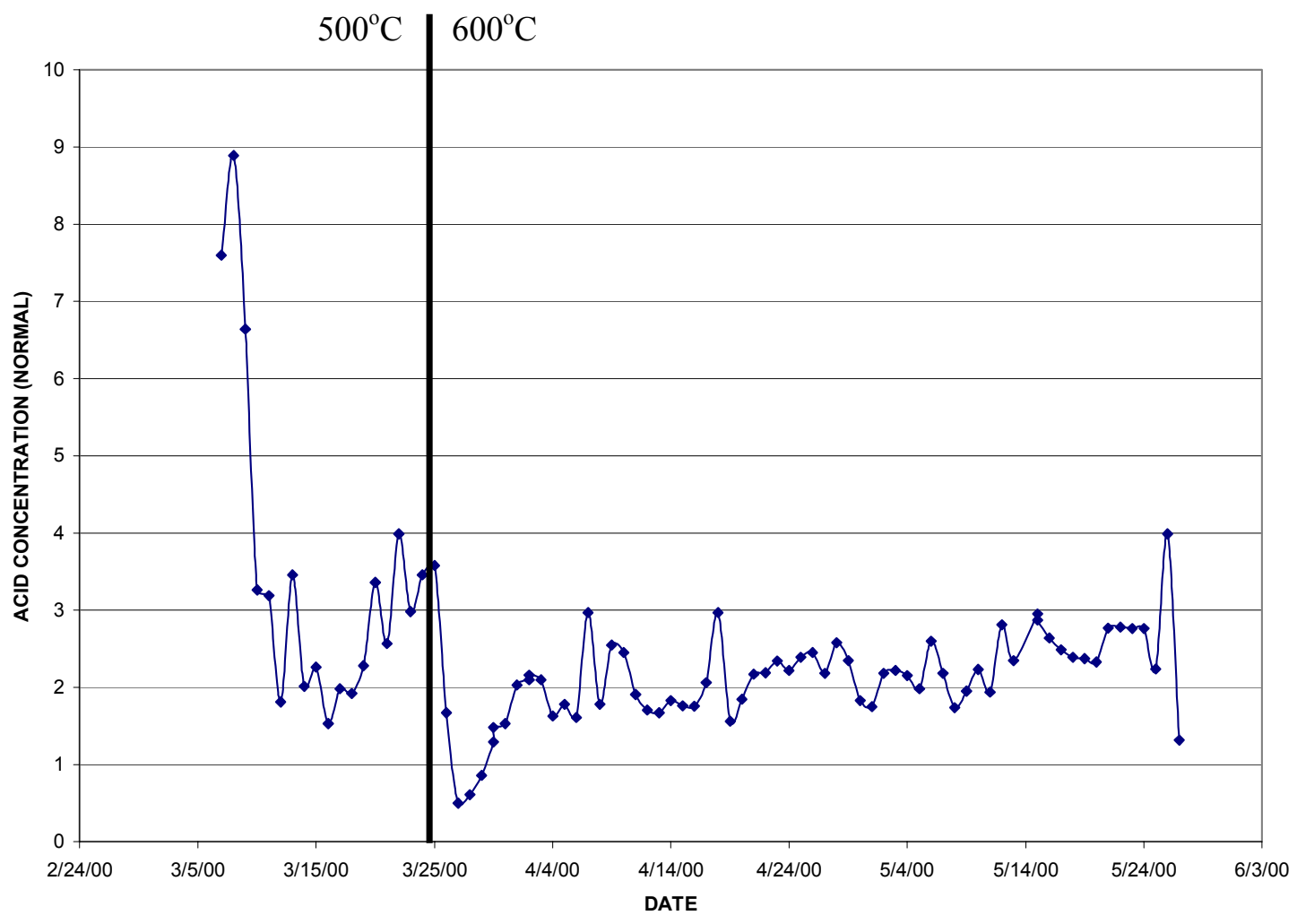

Figure 20. Quench solution acid concentration during Calciner operation in 2000.

The acid began very high (prior to Calciner operation) then quickly dropped to a stable range of 1.5 to 3.0 normal acid when Calciner operations began. A dip in the acid concentration occurred on March 26. The dip followed the transition to the high-temperature flowsheet on March 25. The flow-sheet transition resulted in a temporary increase in fines carryover into the quench system which resulted in a temporary drop in acid concentration. The data show the acid quickly returned to its normal concentration. Even with the temporary upset, every single sample result is above the test criterion value of 0.5 normal acid. The quench solution acid concentration met the test criterion.

Specific gravity is another quench solution parameter used to monitor the overall well being of the quench solution. Although it is the least specific of the quench solution parameters, it is probably the most used simply because operators have access to a continuous, real-time, specific gravity (density) instrument. Other parameters such as acid and chloride concentration come from sample results that require several hours and sometimes days for the analyses to be completed. The test criterion mandated the specific gravity be maintained less than 1.4. A high specific gravity usually indicates the presence of large quantities of solids, both dissolved and undissolved, in the quench solution. This often leads to high acidaddition rates and large volumes of quench solution recycle, lowering the net Calciner feed rate. Figure 
21 shows the quench solution specific gravity (density) from the continuous, on-line monitor used by operators.

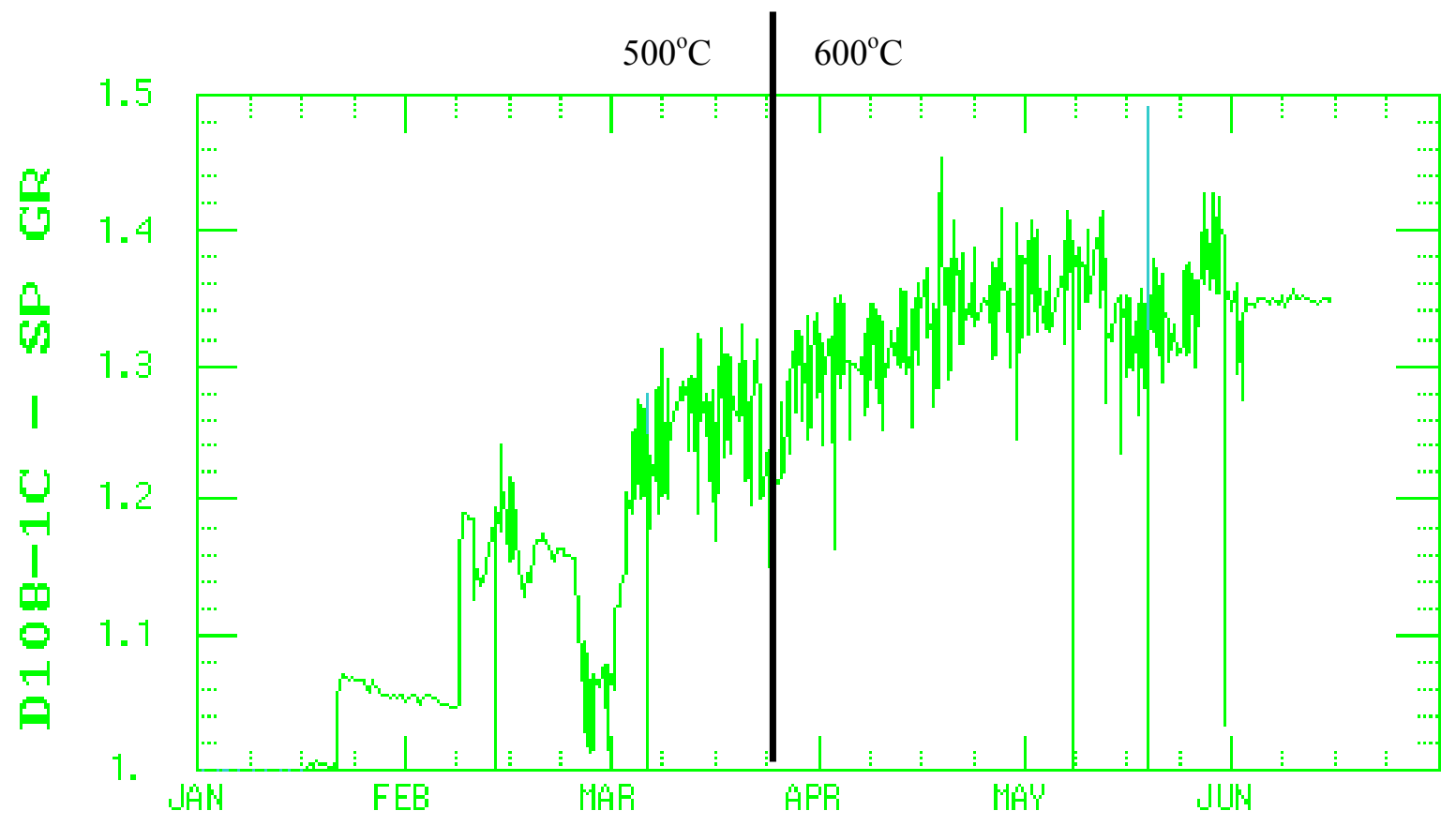

Figure 21. Calciner quench solution density (specific gravity) during 2000 Calciner operation.

Figure 21 shows a steady increase in quench solution density beginning in late March (start of the hightemperature test) and continuing through most of April. The density then leveled out for the last month of operation at a value of about 1.35. The density values met the high-temperature test criterion.

\subsection{Off-gas Line Pressure Drop}

Criterion 12. The pressure drop from the Calciner to Quench Tower maintained at less than 15 inches of water.

Pressure drop through all equipment is an important parameter. An increase or decrease in pressure drop can adversely affect the performance of equipment. Most of the pressure drops through the Calciner equipment were not specific high-temperature criteria, because there was no reason to expect the equipment to perform any differently at $600^{\circ} \mathrm{C}$ from that at $500^{\circ} \mathrm{C}$. High-temperature operation in 1999 confirmed this for most equipment. However, Calciner operation in 1999 ended with an unscheduled shutdown due to high pressure drop caused by a restriction (plug) in the off-gas line immediately downstream of the cyclone (VES-NCC-107). This phenomenon had never occurred before. Some personnel linked the formation of the plug to high-temperature calcination.

A thorough evaluation (Reference 3) of the line restriction concluded the cause was not high-temperature operation. Instead, the cause was an intentional change in operating temperature from $600^{\circ} \mathrm{C}$ to $500^{\circ} \mathrm{C}$. Because of the temperature transition, a layer of calcine dust in the off-gas line absorbed NOx from the offgas and turned into "sticky" sodium nitrate. The sodium nitrate expanded in volume. It also agglomerated with additional calcine dust (due to its "sticky" characteristic) present in the offgas that 
entered line. The expansion and growth of the calcine dust in the off-gas line restricted the flow of offgas, resulting in the Calciner shutdown. The evaluation concluded high-temperature operation could be conducted without risk of line plugging if operating temperature changes were eliminated. Operations personnel made changes to procedures to eliminate switching back and forth between operating temperatures. This criterion monitored the pressure drop in the portion of line that plugged in 1999 to confirm the restriction did not recur during long-term, high-temperature operation.

Figure 22 shows two data trends for the high-temperature operation in April 1999 when the cyclone offgas line plugged.

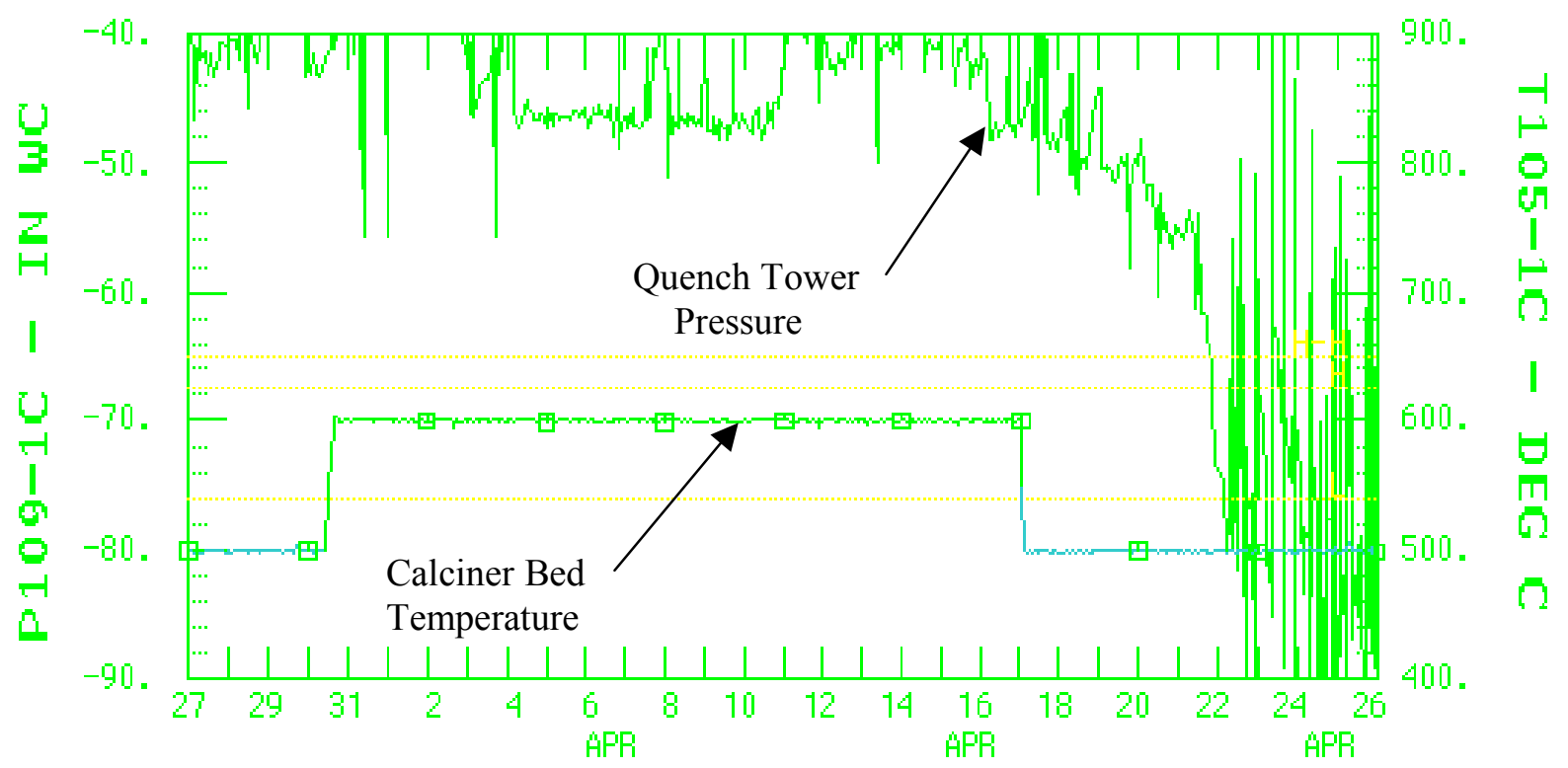

Figure 22. Quench tower pressure during April 1999 when the cyclone off-gas line plugged.

The bed temperature data (lower data plot) show the Calciner operated at $500^{\circ} \mathrm{C}$ until March 301999 , then at $600^{\circ} \mathrm{C}$ until April 17, and then at $500^{\circ} \mathrm{C}$. The upper data plot on Figure 22 is the pressure in the quench tower. It shows normal operation (fluctuating between 40 and 50 inches of water vacuum) until April 17. Between April 17 and April 24, after the bed temperature was reduced to $500^{\circ} \mathrm{C}$, the quench tower vacuum increased to 90 inches. During that time, the cyclone vacuum (not shown on figure) remained constant at its normal value of 40 to 45 inches. The dramatic increase in quench tower vacuum was due to the formation of the off-gas line restriction between the cyclone and the quench tower. Between April 17 and April 24 the pressure drop between the cyclone and quench tower increased from virtually nothing (less than 5 inches) to nearly 50 inches. The off-gas line pressure drop increased even further when the Calciner went through another similar operating temperature cycle in May 1999 (not shown on Figure 22).

Figure 23 shows the same data, bed temperature and quench tower vacuum, as Figure 22 for the 2000 high-temperature operation. 


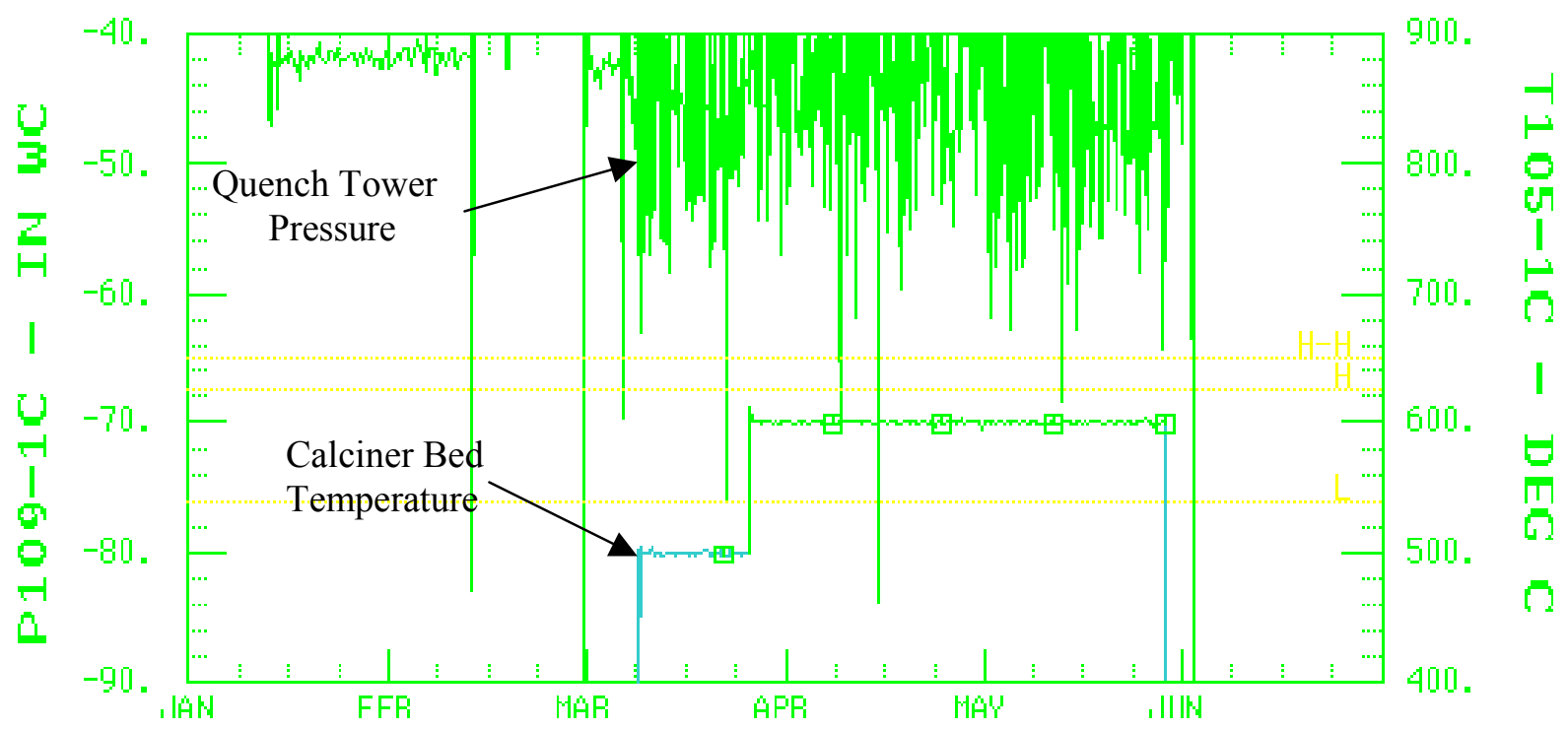

Figure 23. Quench tower pressure during the 2000 operation with no off-gas line plugging.

The quench tower vacuum (upper data trend on the plot) is in its normal 40 to 50 inches of water range for the entire duration of the run. The bed temperature (lower data trend) shows the initial Calciner operation at $500^{\circ} \mathrm{C}$ and the transition to $600^{\circ} \mathrm{C}$. There was no change in temperature back to $500^{\circ} \mathrm{C}$ as there was in 1999, and the off-gas line did not plug.

Due to the concern over the off-gas line restriction, a special instrument (PD105-12) was configured to monitor the pressure drop in the portion of off-gas line that plugged in 1999. Figure 24 shows data from that instrument during high-temperature operation in April 2000.

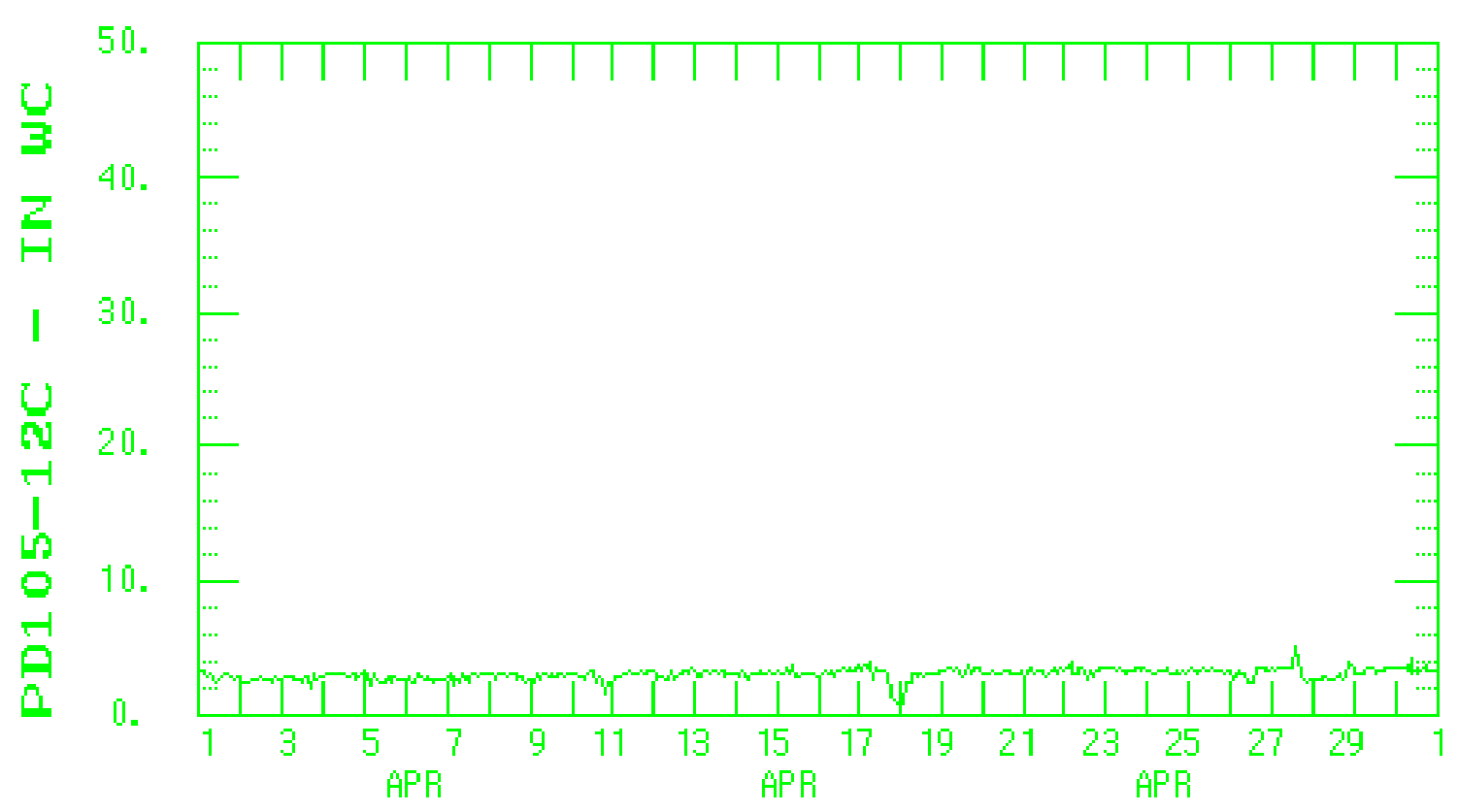

Figure 24. Special off-gas line pressure-drop data during April 2000 high-temperature operation. 
Figure 24 shows the pressure drop in the cyclone off-gas line was a constant 3 inches during hightemperature operation. The range (50 inches of water) of the data plot is for comparison with the April 1999 data (Figure 22) when the off-gas line plugged. In April 1999 the pressure drop started at about 3 inches and increased to 50 inches in a one-week period. There was no increase in the pressure drop in the off-gas line during the entire 2000 operation.

The data show there were no problems with off-gas line restrictions or pressure drops during the hightemperature run in 2000. The high-temperature test confirmed the restriction was not caused by operating the Calciner at $600^{\circ} \mathrm{C}$. The off-gas line pressure drop met its criterion of less than 15 inches of water.

\subsection{Calciner Cell Temperature}

Criterion 13. The Calciner cell temperature maintained at or below $160^{\circ} \mathrm{F}$.

The thermally hot Calciner vessel releases large quantities of heat to the Calciner cell during operation. The Calciner cell heating and ventilation $(\mathrm{H} \& \mathrm{~V})$ system removes the heat from the cell. Increasing the Calciner temperature to $600^{\circ} \mathrm{C}$ increases the heat load to the cell by approximately $20 \%$. A temperature limit for the Calciner cell exists to protect equipment from thermal degradation. High temperatures could damage equipment such as shield window seals, air supply hoses, and other equipment made of elastomers. This criterion is to verify the Calciner cell H\&V system can remove the additional heat load during high-temperature operation by keeping the cell less than $160^{\circ} \mathrm{F}$.

Figure 25 shows the Calciner cell temperature in late March and early April 2000.

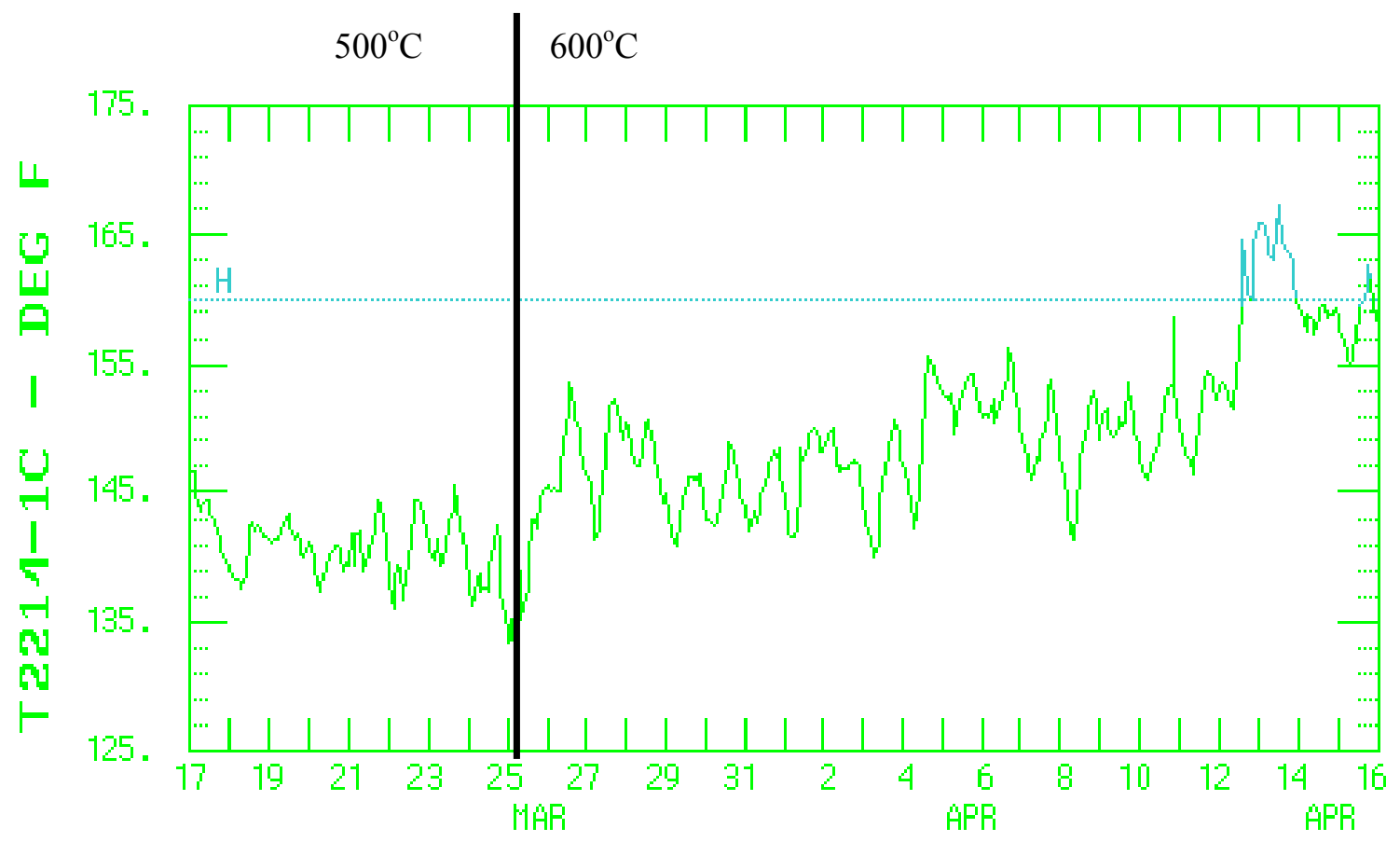

Figure 25. Calciner cell temperature in 2000 during the high-temperature transition.

Figure 25 shows the cell temperature had a diurnal temperature oscillation of about 10 degrees Fahrenheit. The temperature reached a maximum in the late afternoon, and cooled during the night. 
Figure 25 also shows the average cell temperature gradually increased with time. This corresponds to the season of the year, and the fact that the outside air gradually increased in temperature. The data are within the acceptable range (less than $160^{\circ} \mathrm{F}$ ) except for some brief periods at the end of the data plot.

Figure 26 shows Calciner cell temperature data (upper set of data) in late April and early May 2000.

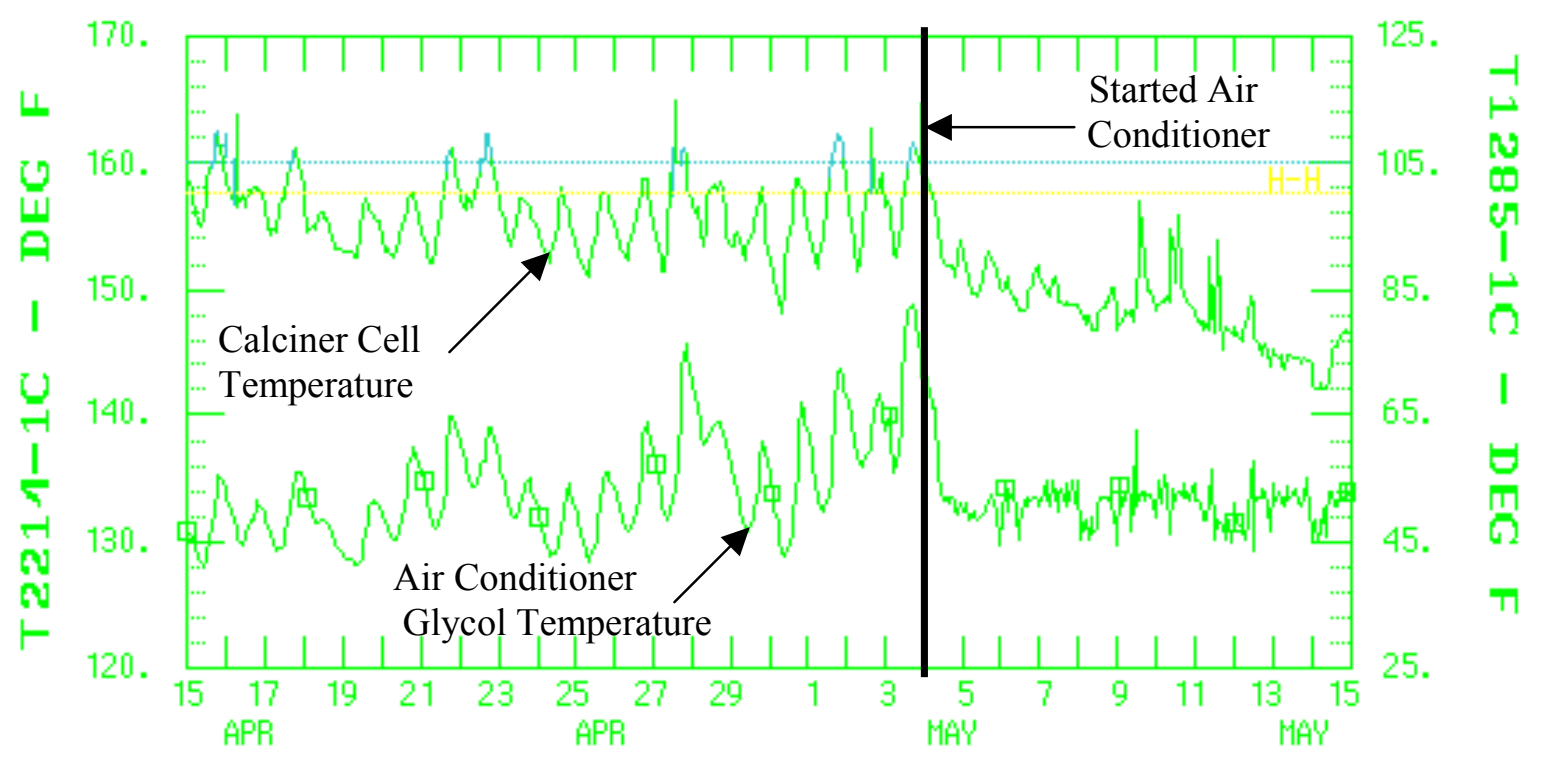

Figure 26. Calciner cell and air conditioning system temperatures during high-temperature operation.

Figure 26 shows the cell temperature occasionally exceeded the limit of $160^{\circ} \mathrm{F}$ prior to May 4 . However, on May 4, a step change occurred and the cell temperature dropped dramatically, never exceeding $160^{\circ} \mathrm{F}$ after that. The lower set of data on Figure 26 contains the reason for the sudden decrease in Calciner cell temperature. The lower set of data (T1285-1C) is the temperature of the circulating glycol solution used in the Calciner $\mathrm{H} \& \mathrm{~V}$ air-conditioning unit. Prior to May 4, the glycol temperature had the same diurnal cycles as the cell temperature, going from a low of about $40^{\circ} \mathrm{F}$ to a high of $80^{\circ} \mathrm{F}$. During that time, the air conditioner was off, and the glycol temperature reflects the ambient air temperature. On May 4, operators placed the Calciner $\mathrm{H} \& \mathrm{~V}$ air conditioner in service. This is shown as the constant, $50^{\circ} \mathrm{F}$ glycol temperature after May 4. Placing the air conditioner in service caused the Calciner cell temperature to drop well below the alarm point and remain there.

Although there were some instances where the Calciner cell temperature went above $160^{\circ} \mathrm{F}$, the operating data show such instances can be prevented or controlled using existing plant air conditioning equipment. Therefore, the cell temperature met its criterion. It is also noted that a recommended upgrade (Reference 1) to the Calciner H\&V fans to increase the flow of air to the Calciner cell and help cool the cell has not been implemented. Implementation of that recommendation could be pursued to further cool the cell.

\subsection{Stable Operation}

Criterion 14. Operation for 30 days at a stable feed blend ratio.

The purpose of this criterion is to show the Calciner can operate on the high-temperature flowsheet for an extended period. Some Calciner operating parameters change slowly, sometimes taking several days to 
reach a new equilibrium point following a process change. Because of this, a two or three day operating period is inadequate to demonstrate long-term viability of the flowsheet. Operation for a one-month period (test criteria value) has historically been sufficiently long to demonstrate flowsheet viability. The Calciner began high-temperature operation on March 25. High-temperature operation continued through May 24, a two-month period. The high-temperature test run met the stable operation criterion of 30 days of stable operation. The operating parameters significant to stable operation such as Calciner vacuum, Calciner temperatures, off-gas pressures, quench solution chemical composition, etc., have already been discussed in detail. 


\section{SIGNIFICANT NON-CRITERIA CALCINER DATA}

\subsection{Data Not Included in Test Criteria}

Calciner operating data relevant to the specific high-temperature test criteria are discussed in section 4 of this report. The following section discusses notable Calciner operating data and events, both good and bad, which were not part of any of the previous specific test criteria.

\subsection{NOx Release During Bed Temperature Transition}

During the two-month high-temperature test there was only one significant negative event related to hightemperature operation. That event occurred on March 25 and involved the transition from $500^{\circ} \mathrm{C}$ to $600^{\circ} \mathrm{C}$. On March 25 the Calciner vessel contained $500^{\circ} \mathrm{C}$ flowsheet calcine. This calcine was high in sodium nitrate. The bed "denitrated" (sodium nitrate became sodium aluminate) as the Calciner operating temperature was increased to $600^{\circ} \mathrm{C}$. The denitration reaction resulted in the evolution of considerable NOx that had been tied up as sodium nitrate in the bed. This reaction occurred very rapidly and the NOx discharge rate from the main stack slightly exceeded the allowed value for a few minutes. From a technical standpoint, the excess amount of NOx discharged was very small, and was not a threat to human health or the environment. However, it was a politically sensitive issue that could have been prevented.

Figure 27 shows two parameters, bed temperature and NOx release, during the temperature transition from $500^{\circ} \mathrm{C}$ to $600^{\circ} \mathrm{C}$ on March 25, 2000.

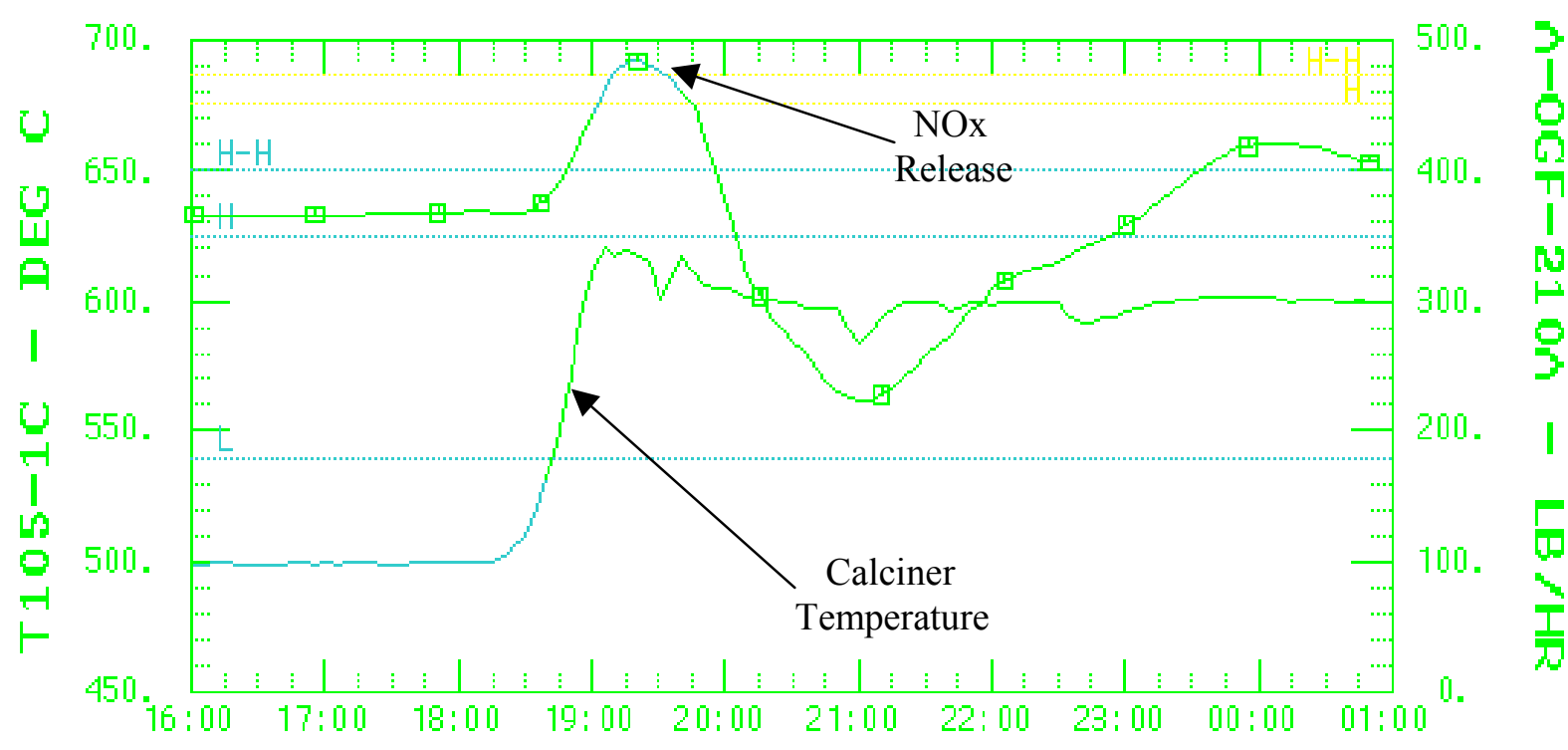

Figure 27. Elevated NOx release during Calciner high-temperature transition in March 2000. 
The Calciner temperature went from $500^{\circ} \mathrm{C}$ to $600^{\circ} \mathrm{C}$ between 1830 hours and 1900 hours, a period of only 30 minutes. During that time, the bed denitrated, and the NOx release rate increased from about 370 $\mathrm{lb} / \mathrm{hr}$ to about $482 \mathrm{lb} / \mathrm{hr}$ (the limit is $472 \mathrm{lb} / \mathrm{hr}$ ).

This was not the first time the high-temperature transition had been made. Figure 28 shows the hightemperature transition data from March 30 1999, the first such transition ever done. Both the vertical and horizontal scales on Figures 27 and 28 are the same for ease of comparison. The temperature transition on March 30, 1999 did not increase the release rate of NOx, nor were any limits exceeded. There were two main reasons for this. One was the amount of time taken to make the temperature transition. In March 2000, the temperature transition took only 30 minutes, during which time all of the NOx evolved from the Calciner bed, resulting in a high NOx concentration for a short time. In 1999, the temperature transition took 6 hours, thus spreading the denitration and evolution of NOx out over a longer period. Though not shown on either data plot, the feed rate in 1999 was also lower than in 2000, thus less NOx was generated from the feed to add to that of the bed denitration. Parameters such as the feed rate and rate of temperature increase are controlled by operators and can be procedurally mandated to prevent exceeding NOx limits in the future.

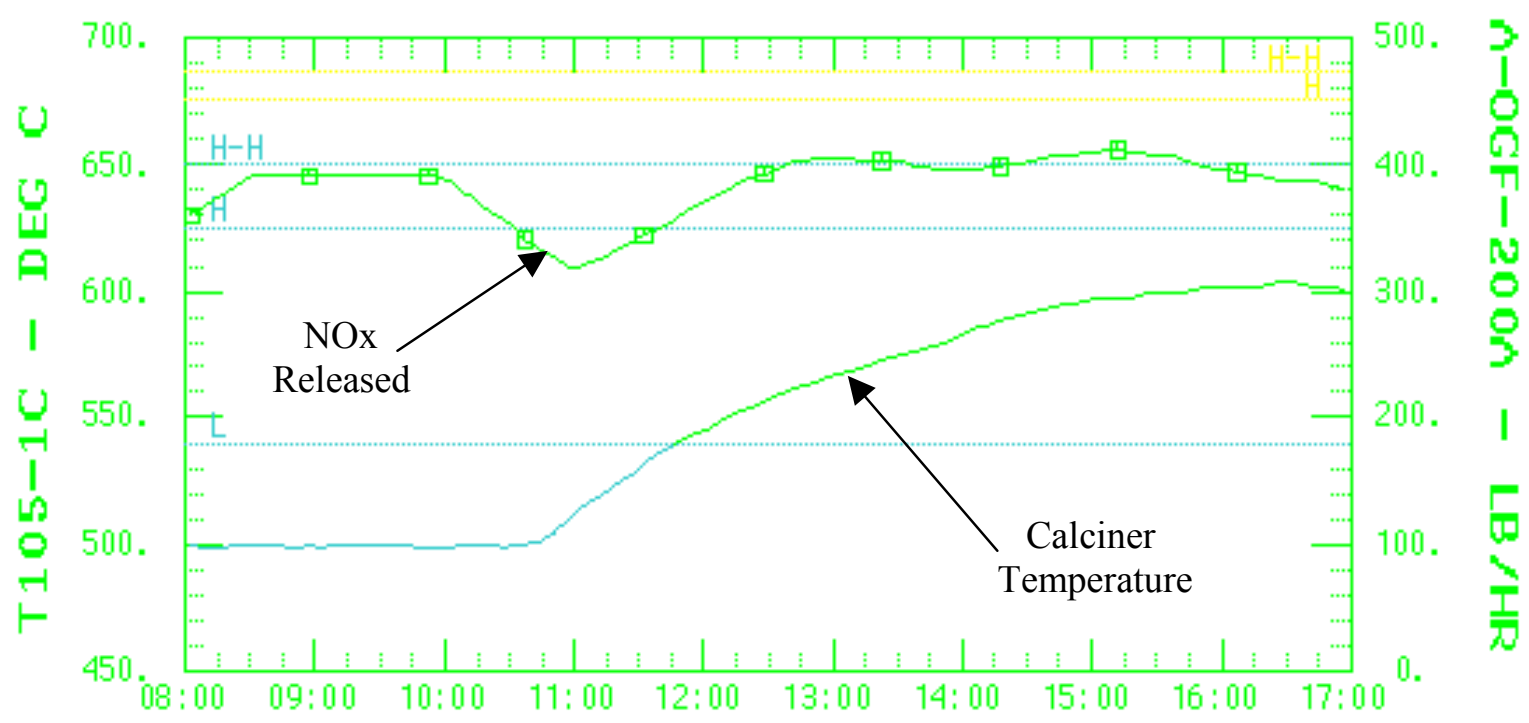

Figure 28. Normal NOx release during Calciner high-temperature transition in March 1999.

\subsection{Quench Solution Deep Recycle}

There were several noteworthy items from the high-temperature operation that were not part of any specific acceptance criteria, but should be discussed. The first is quench solution recycle. Section 4.9 of this report discusses the recycle of quench solution into the Calciner feed system. Another quench solution transfer route is to the Tank Farm. During the high-temperature operation there were no quench solution transfers made to the Tank Farm.

Historically, it has been normal $\left(\right.$ at $500^{\circ} \mathrm{C}$ ) to recycle quench solution back to the Tank Farm on a periodic basis. This was usually the result of one of two situations. At startup or during a flow-sheet transition, a higher-than-normal fines carryover into the quench system occurs. This results in low quench system acidity, high undissolved solids, and high quench solution specific gravity. The usual method of recovery is to send some of the quench solution (1000 to 1500 gallons) to the Tank Farm and refill the quench hold tank with fresh acid. This operation is often called a "deep recycle". During 2000, an effort was made to 
not send any waste to the Tank Farm from NWCF to help in the material balance done in conjunction with the off-gas sampling. A broken valve in the quench system actually helped in this effort by forcing the use of the NWCF hot sump tank (VES-NCC-119) as a surge tank for quench solution. Using the hot sump tank for quench solution provided short-term interim storage for solution which would normally have been sent to the Tank Farm. This quench solution was gradually recycled into the feed system after the quench system reached equilibrium, instead of being sent to the Tank Farm.

Another reason for sending quench solution to the Tank Farm is chloride buildup in the quench solution. Chloride in the Calciner feed solution builds up in the scrub solution because of the volatility of chloride in the Calciner vessel. Chloride increases the potential for certain types of corrosion (stress corrosion cracking) in the quench system. In order to minimize the corrosion potential in the quench system, upper limits are in place for the amount of chloride allowed in the quench solution. Currently the limit is 5000 ppm. When the chloride reaches $5000 \mathrm{ppm}$, operators perform a deep recycle, sending quench solution to the Tank Farm and then refilling the quench system with fresh acid. During the high-temperature operation, chloride volatility was practially nonexistant. The chloride level in the quench system stabilized at 1000 to $1500 \mathrm{ppm}$ and remained there for the duration of the operation. Consequently there were no deep recycles, and no quench solution was sent to the Tank Farm.

Not sending quench solution to the Tank Farm is significant because all of the models of future waste calcination assume deep recycles occur, periodically sending some quench solution to the Tank Farm. The volume of such deep recycles is typically assumed to be about 3000 gallons per month. Over time, elimination of the deep recycles would be a significant savings in waste generation from that assumed based on past Calciner flowsheets. This would increase the efficiency of the Calciner and its net waste processing rate.

\subsection{Amount of Sodium Waste Calcined}

Another noteable item was the large amount of SBW successfully bended into the feed batches. The purpose of the high-temperature flowsheet is to increase the net calcining rate of SBW. Feed blends are usually measured by their sodium and potassium content. Liquid waste is blended with aluminum nitrate (ANN) to achieve a given molar ratio of aluminum to the sum of sodium and potassium $(\mathrm{Al} / \mathrm{Na}+\mathrm{K})$. The high-temperature flowsheet increases the net calcining rate of SBW by decreasing the amount of ANN added to each feed batch and decreasing the $\mathrm{Al} / \mathrm{Na}+\mathrm{K}$ ratio. Calcine is also measured in terms of its sodium and potassium content. It is usually given in terms of the molar percentage of the sodium and potassium contained in the calcine $(\mathrm{mole} \% \mathrm{Na}+\mathrm{K})$.

The high-temperature criteria letter (Reference 4) contained two potential feed blends for processing the waste from Tank Farm vessel VES-WM-189. One feed blend had a $\mathrm{Al} / \mathrm{Na}+\mathrm{K}$ ratio of 3.2, resulting in $9.6 \mathrm{~mole} \% \mathrm{Na}+\mathrm{K}$ in the calcine. The criteria letter called this blend "optimistic", implying calcining waste with such a high amount of $\mathrm{Na}+\mathrm{K}$ may not be succussful. The criteria letter contained a second feed blend with a $\mathrm{Al} / \mathrm{Na}+\mathrm{K}$ ratio of 4.0 , resulting in $8.0 \mathrm{~mole} \% \mathrm{Na}+\mathrm{K}$ in the calcine. This blend was called "more conservative".

The amount of $\mathrm{Na}+\mathrm{K}$ in the waste and subsequently in the calcine is extremely important. Future waste processing models make assumptions on the future feed blends that might be processed. The models then determine potential processing schedules and are used to determine if future milestones can be met. It is important to demonstrate the flowsheets assumed in the models for SBW calcinination are valid. Historically, these models have assumed about $8 \mathrm{~mole} \% \mathrm{Na}+\mathrm{K}$ in the calcine.

Figure 29 shows the amount (mole percent) of $\mathrm{Na}+\mathrm{K}$ in the calcine generated during the high-temperature demonstration in 2000. 


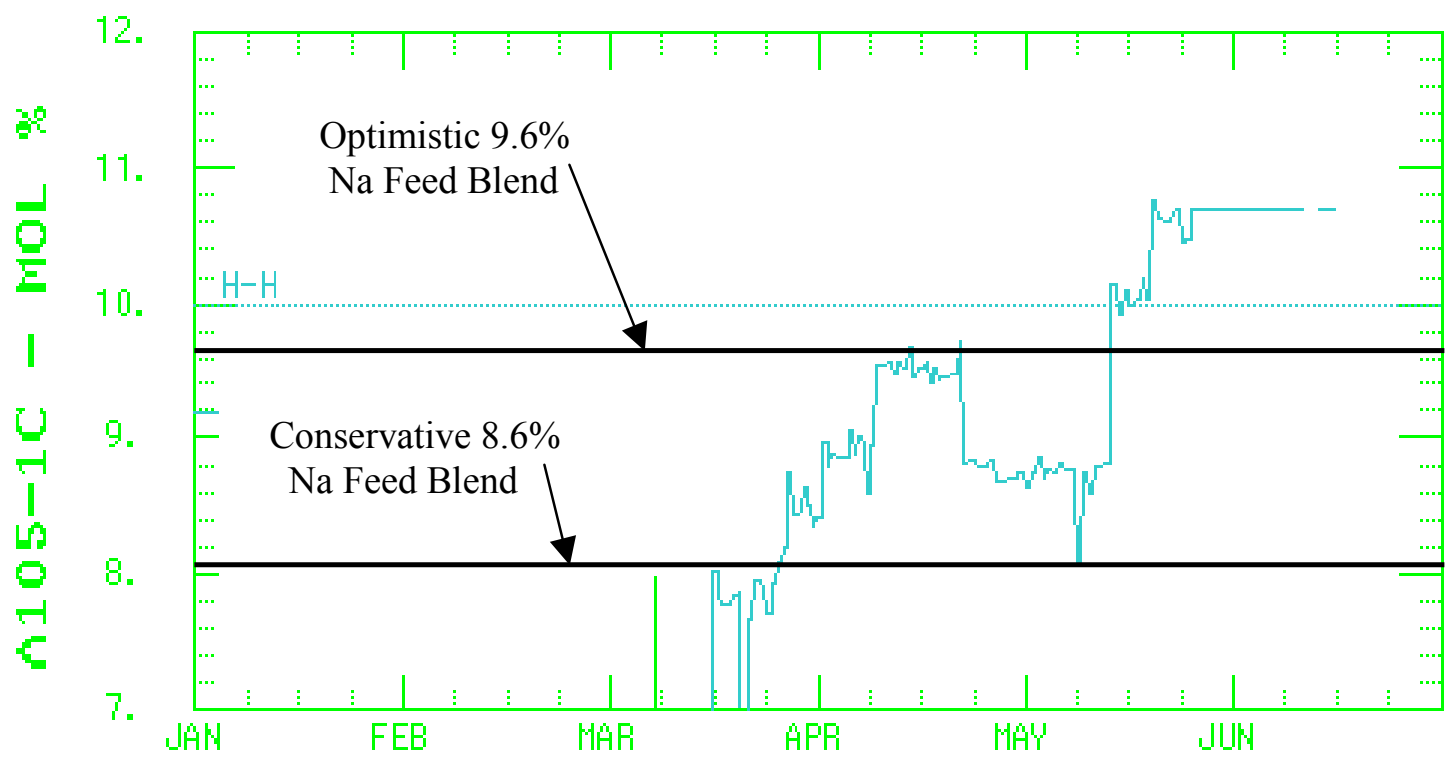

Figure 29. Amount of $\mathrm{Na}+\mathrm{K}$ (mole percent) in the calcine generated in 2000 .

Figure 29 shows the Calciner began operations in March at 7.8 mole $\% \mathrm{Na}+\mathrm{K}$ (at $500^{\circ} \mathrm{C}$ ). As soon as the transition to $600^{\circ} \mathrm{C}$ occurred (March 25), operations personnel steadily increased the amount of SBW in the feed until the $\mathrm{Na}+\mathrm{K}$ in the calcine was $9.6 \mathrm{~mole} \%$ (mid April). The amount of SBW was then reduced to generate calcine with a $\mathrm{Na}+\mathrm{K}$ value of $8.8 \mathrm{~mole} \%$ while the bed particle size stabililized. The SBW in the feed was increased again (mid May) after the bed particle size stabilized, until the final waste feed batches were producing calcine with a $\mathrm{Na}+\mathrm{K}$ content of $10.6 \mathrm{~mole} \%$.

The amount of SBW added to the feed blend exceeded the high-temperature criteria. The entire hightemperature operating period was above the "conservative" test criteria blend value of $8.0 \mathrm{~mole} \% \mathrm{Na}+\mathrm{K}$. A significant amount of waste was processed which exceeded even the "optimistic" test criteria blend value of 9.6 mole $\% \mathrm{Na}+\mathrm{K}$. The final feed batches (generating 10.6 mole $\% \mathrm{Na}+\mathrm{K}$ ) contained $33 \%$ more SBW than the conservative criteria feed blend, and 10\% more SBW than even the optimistic criteria feed blend. The high-temperature test demonstrated the new flowsheet can easily meet and likely exceed the waste processing rates used in future waste modeling programs.

\subsection{Tank Farm Waste Calcination Difficulty}

During 2000, the Calciner processed 87,000 gallons of waste from Tank Farm vessel VES-WM-189, most of it during the high-temperature test, nearly emptying the tank. The waste from VES-WM-189 was projected to be the most difficult waste to calcine of all that remaining in the Tank Farm. This is because of the unique chemistry and some of the chemical constituents of that particular waste (such as more fluorid than typical SBW). The composition of VES-WM-189 is shown in Table 1.

Table 1. Tank Farm VES-WM-189 waste composition (sampled November 1998). 


\begin{tabular}{|c|c|c|}
\hline \multicolumn{2}{|c|}{ Chemical Species } & Concentration \\
\hline \multicolumn{2}{|l|}{ Snecific Gravitv } & 13070 \\
\hline Acid & $(\mathrm{H}+, \mathrm{M})$ & 2.570 \\
\hline Nitrate & $(\mathrm{NO} 3, \mathrm{M})$ & 6.230 \\
\hline Aluminum & $(\mathrm{Al}, \mathrm{M})$ & 0.8884 \\
\hline Boron & $(\mathrm{B}, \mathrm{M})$ & 0.0250 \\
\hline Cadmium & $(\mathrm{Cd}, \mathrm{M})$ & 0.0048 \\
\hline Calcium & $(\mathrm{Ca}, \mathrm{M})$ & 0.0840 \\
\hline Chloride & $(\mathrm{Cl}, \mathrm{M})$ & 0.0241 \\
\hline Chromium & $(\mathrm{Cr}, \mathrm{M})$ & 0.0046 \\
\hline Fluoride & $(\mathrm{F}, \mathrm{M})$ & 0.2357 \\
\hline Lead & $(\mathrm{Pb}, \mathrm{M})$ & 0.0011 \\
\hline Manganese & $(\mathrm{Mn}, \mathrm{M})$ & 0.0116 \\
\hline Iron & $(\mathrm{Fe}, \mathrm{M})$ & 0.0250 \\
\hline Mercury* & $(\mathrm{Hg}, \mathrm{M})$ & 0.0156 \\
\hline Nickel & $(\mathrm{Ni}, \mathrm{M})$ & $<0.0020$ \\
\hline Phosphate & $(\mathrm{PO} 4, \mathrm{M})$ & 0.0003 \\
\hline Potassium & $(\mathrm{K}, \mathrm{M})$ & 0.1141 \\
\hline Sodium & $(\mathrm{Na}, \mathrm{M})$ & 0.9013 \\
\hline Sulfate & $(\mathrm{SO} 4, \mathrm{M})$ & 0.0067 \\
\hline Zirconium & $(\mathrm{Zr}, \mathrm{M})$ & 0.0357 \\
\hline Undissolved Solids & (UDS, g/l) & 1.1 \\
\hline \multicolumn{3}{|c|}{$\begin{array}{c}\text { Radionuclides } \\
\end{array}$} \\
\hline Cesium 134 & $(\mathrm{Cs}-134, \mathrm{mCi} / \mathrm{l})$ & 0.210 \\
\hline Cesium 137 & (Cs-137, mCi/l) & 122 \\
\hline Europium-154 & $(\mathrm{Eu}-154, \mathrm{mCi} / \mathrm{l})$ & 0.410 \\
\hline Strontium-90 & $(\mathrm{Sr}-90, \mathrm{mCi} / 1)$ & 111 \\
\hline Tritium & $(\mathrm{H}-3, \mathrm{mCi} / \mathrm{l})$ & 0.0230 \\
\hline Uranium & $(\mathrm{U}, \mathrm{mg} / \mathrm{l})$ & 55 \\
\hline Heat Generation Rat & $\left(\mathrm{W} / \mathrm{m}^{3}\right)$ & 1.364 \\
\hline
\end{tabular}

* Mercury value (only) is from a March 1999 sample.

** Radionuclide values are not corrected for decay.

Calcining waste from VES-WM-189 was expected to be difficult was based on pilot plant tests and operating experience. The high-temperature criteria letter to DOE reflected this expectation in the list of feed blends for various waste tanks. The criteria letter contained feed blends for three Tank Farm wastes (VES-WM-180, VES-WM-185, and VES-WM-189). Of the three waste blends, the blend for VES-WM189 had the least amount of SBW in each feed batch, and the lowest mole $\% \mathrm{Na}+\mathrm{K}$ in the calcine, because of the difficulty calcining it in the pilot plant. Based on pilot plant experience, the other SBW will be easier to calcine, and can be calcined with more SBW in each feed batch resulting in a higher net processing rate.

Having calcined the most difficult waste, at rates above those expected in the criteria letter and used in future waste modeling programs, adds a significant degree of confidence of being able to meet future SBW processing milestones with the new high-temperature calcining flowsheet. 


\section{CONCLUSIONS}

The Calciner operated with a new high-temperature flowsheet for a two-month period from March 25 to May 24, 2000. The purpose of the new flowsheet is to increase the net processing rate of SBW. The new flowsheet solves a major historical SBW calcining problem by creating solids that do not melt and agglomerate at Calciner operating temperatures. The result is more radioactive waste and less chemical additives are processed in each batch of Calciner feed. The Calciner met all significant high-temperature test criteria. There were two criteria which were not fully met. One was the upper value for the oxygento-fuel ratio. The upper value of the oxygen-to-fuel ratio has no significance to either Calciner safety or operation. Operating personnel increased this parameter above the test criterion range to help control calcine particle size. Because the Calciner met the significant lower value for the oxygen-to-fuel ratio, the operation was considered successful. The other criterion that was not fully met was to maintain the NAR below 450. The basis for the value of 450 was higher NAR values have historically resulted in undesirable process upsets. These upsets include excessive fines carryover, inability to build bed, etc. These problems did not occur during the high-temperature test. The high-temperature test proved the new flowsheet calcine is sufficiently different from that of the past that higher values of the NAR are acceptable for operation.

In addition to meeting the predetermined test criteria, the high-temperature operation had other significant benefits. The chloride volatility from the Calciner into the quench system improved (decreased) compared to that of historical operation. Consequently, there was no quench solution returned to the Tank Farm (deep recycle) during the high-temperature run. Waste from the most difficult tank to calcine (WM-189) was successfully calcined, and the amount of sodium contained in each feed batch exceeded even the optimistic feed blend criteria.

The high-temperature test demonstrated the new flowsheet is a viable, long-term method of calcining waste to reliably meet future waste processing milestones. 


\section{REFERENCES}

1. R. D. Boardman, D. E. Keller, and D. B. Lord, "NWCF Process Modification for Sodium-Bearing Waste Project Final Design Report”, INEEL/INT-98-00146, September 1998.

2. R. A. Wood letter to D. W. Marshall, "Transmittal of NWCF High-Temperature Trial Report for FY1999”, RAW-08-99, September 30, 1999.

3. J. H. Valentine letter to J. T. Case, "Transmittal of NWCF Off-Gas Line Restriction Identification and Resolution Report”, CCN \# 00-001609, November 8, 1999.

4. J. H. Valentine letter to J. T. Case, "NWCF High-Temperature Test Criteria", November 30, 1999. 